\title{
A TUTELA DOS DIREITOS FUNDAMENTAIS E O STF COMO "LEGISLADOR POSITIVO"
}

\author{
THE PROTECTION OF FUNDAMENTAL RIGHTS \\ AND FEDERAL SUPREME COURT (STF) ACTING AS \\ A "POSITIVE LEGISLATOR"
}

Ingo Wolfgang Sarlet

isarlet@pucrs.br

Rodrigo Vianna

rodrigo.viannna@yahoo.com.br

Recebido em 03/06/2012

Aprovado em 29/09/2013

SUMÁRIO: Introdução; 1. A efetividade dos direitos fundamentais como imperativo de Justiça Constitucional; 2.A omissão inconstitucional como óbice à eficácia e à efetividade dos direitos fundamentais; 3.A necessária superação da fórmula do "legislador negativo"; 4. A legitimidade da atuação normativa do STF; 5.A efetiva superação da fórmula do "legislador negativo" no processo constitucional; 5.1 Técnicas ditas "atípicas" de decisão; 5.2 Ações constitucionais para o controle da omissão inconstitucional; 6. Pressupostos, características e limites da atuação do STF como "legislador positivo".

\section{RESUMO}

O artigo versa sobre a atuação normativa do STF com o objetivo de assegurar a efetividade dos direitos fundamentais em casos de omissão legislativa inconstitucional. Além de identificar e discutir os principais aspectos do problema da inconstitucionalidade por omissão e propor a superação da fórmula Kelseniana do "legislador negativo", apresenta argumentos de legitimação da atuação normativa do Tribunal Constitucional, designadamente por meio de técnicas "atípicas" de decisão e de ações constitucionais específicas,

\section{ABSTRACT}

The article discusses the normative role of the STF (Brazilian Federal Supreme Court), in order to assure effectiveness to fundamental rights in the case of unconstitutional omission from the legislative branch. Besides identifying and discussing the main aspects of the unconstitutional normative omission and suggesting the overcoming of the classic Kelsenian formula of the "negative legislator", the article presents arguments for legitimating the normative role of the Constitutional Court, mainly while using "atypical" decision techniques and specific constitutional procedures, establishing a distinction between the normative function in a 
estabelecendo distinção entre as funções normativa em sentido amplo e em sentido estrito (função legislativa). Ao final, são analisados os pressupostos, as características e os limites da atuação do STF como "legislador positivo".

\section{PALAVRAS-CHAVE}

Omissão legislativa - direitos fundamentais Supremo Tribunal Federal (STF) - legislador positivo. broad sense and the legislative function in a strict sense. It concludes by analyzing the premises, the characteristics and the limits of the Federal Supreme Court (STF) acting as a "positive legislator".

KEYWORDS

Unconstitutional legislative omission - fundamental rights - Federal Supreme Court (STF) - positive legislator

\section{INTRODUÇÃO}

A afirmação da possibilidade de atuação do Tribunal Constitucional como "legislador positivo", por mais restrita e condicionada que seja, é, mesmo em nossos dias, fonte de grande polêmica e motivo de forte resistência, sobretudo em face do (ainda) profundo enraizamento da rígida concepção liberal de separação de poderes, a que se liga diretamente o axioma (Montesquieu) da neutralidade do Juiz diante da liberdade de conformação do legislador democrático, bem como da ulterior tese kelseniana do Tribunal Constitucional como "legislador negativo", que, nada obstante tenha superado o mito da neutralidade política do Judiciário, vem sendo apropriada como argumento exponencial para a limitação, quando não da negação, da legitimidade de uma atuação normativa em sentido positivo por parte da Justiça Constitucional.

O que aqui se busca demonstrar, com toda a limitação de aprofundamento que a brevidade do trabalho impõe, é que uma atuação, tanto normativa em sentido amplo, como, mais restritamente, materialmente legislativa (normativa em sentido estrito), da Justiça Constitucional, além de não atentar contra o modelo de repartição funcional do poder traçado pela Constituição brasileira, também não ofende o princípio democrático consagrado na nossa Carta Magna, revelando-se, pelo contrário, como sendo essencial à sua proteção e preservação. Com efeito, como se pretende demonstrar, não raras vezes (embora ainda assim em caráter excepcional), a atuação normativa da Justiça Constitucional se afigura como sendo o único meio eficaz de enfrentamento da hipertrofia da discricionariedade legislativa, designadamente quando se cuida da opção de não legislar, visto que tal conduta omissiva acaba por atentar contra a necessária eficácia social (efetividade) dos direitos fundamentais, especialmente naquilo em que dependem da integração legislativa e normativa em sentido amplo para alcançarem a sua plena realização. 
Sem desconhecer a natureza multifacetada da omissão constitucionalmente relevante, o foco do estudo é centrado na omissão legislativa, sobretudo no tocante à negação de densidade normativa suficiente à efetivação dos direitos fundamentais, cujo enfrentamento impõe a superação da fórmula do "legislador negativo", que é abordada, não só quanto ao próprio questionamento da natureza da clássica função de controle de constitucionalidade das leis, como em relação à sua manifesta insuficiência, notadamente em face da crescente complexidade funcional da Justiça Constitucional, bem como diante da necessidade de superar o seu ainda evidente déficit procedimental e interpretativo.

$\mathrm{Na}$ sequência, apresenta-se uma síntese de argumentos sustentadores da legitimidade da atuação normativa da Justiça Constitucional e, mais especificamente, do STF, para, subsequentemente, analisar-se a efetiva superação da fórmula do "legislador negativo" nesse Tribunal, quer mediante o manejo de técnicas ditas "atípicas" de decisão, brevemente mencionadas, quer no exercício da jurisdição no âmbito das ações constitucionais voltadas ao controle da omissão inconstitucional, destacando-se a atuação normativa em sentido amplo nas primeiras, ao passo que, em sede de mandado de injunção, é possível sustentar o exercício de uma função materialmente legislativa, portanto, normativa em sentido estrito. Por fim, são abordados os pressupostos, as características e os limites dessa atuação legislativa "positiva", de modo a aclarar que ela não implica suplantação, tampouco substituição do legislador.

O método de abordagem empregado é predominantemente dedutivo, partindo de noções gerais acerca da eficácia e efetividade dos direitos fundamentais, da arquitetura constitucional determinante da repartição e do compartilhamento do exercício das funções emanadas do poder do Estado, da democracia e da omissão constitucionalmente relevante, para alcançar conclusões específicas acerca do papel a ser desempenhado pelo Supremo Tribunal Federal na tarefa de assegurar eficácia e efetividade aos direitos fundamentais frente à inconstitucionalidade por omissão normativa, culminando com a confirmação empírica de uma legítima atuação normativa positiva por parte da Suprema Corte brasileira, devidamente amparada na análise de julgados paradigmáticos nessa seara.

\section{A Efetividade dos Direitos Fundamentais como Função e Dever da Justiça Constitucional}

O Estado Constitucional de Direito se caracteriza pela supremacia da Constituição, que informa e conforma todo o ordenamento jurídico, tanto no âmbito público, como no privado. A supremacia da Constituição, por sua vez, assenta sobre dois fundamentais pilares de sustentação: a rigidez constitucional e a correlata Justiça Constitucional. A primeira consiste na imposição de restrições e 
de procedimento mais dificultoso do que aquele empregado no processo legislativo ordinário para a reforma da Constituição, evitando que os grandes vetores de conformação do ordenamento jurídico restem à disposição da vontade de oscilantes maiorias parlamentares ocasionais, preservando, assim, a estabilidade do Estado Democrático de Direito. A segunda, caracteriza-se como jurisdição incumbida da elevada finalidade de defesa e aplicação da Constituição e, para além disso, da implementação dos princípios e do programa Constitucionais.

Nesse sentido, TAVARES (2005) enfatiza que a Justiça Constitucional não se resume à tradicional tarefa de controle de legitimidade constitucional das leis, envolvendo o controle dos atos estatais em geral, bem como questões de distribuição de competências, resolução de atritos entre poderes, governabilidade e outras matérias consentâneas à estabilidade e a harmonia do complexo sistema jurídico-constitucional contemporâneo ${ }^{1}$. Portanto, ocupando os direitos fundamentais posição de primazia no Ordenamento Constitucional, a sua proteção e promoção assume a condição de uma das principais, senão mesmo a principal, função da Justiça Constitucional. Tal função (que corresponde também a um dever) implica, acima de tudo, assegurar aos direitos fundamentais a sua máxima eficácia e efetividade, assumindo-se, nesse contexto, a premissa de que tais direitos, para além de constituírem direitos subjetivos oponíveis ao Estado (e mesmo aos particulares), possuem uma dimensão objetiva informadora e conformadora de toda a ordem jurídica, vinculando, sobretudo o poder público, sem exclusão da sociedade como um todo, ao seu respeito, proteção e promoção.

Relembre-se, nesta quadra, que de acordo com o art. $5^{\circ}, \int 1^{\circ}$, da Constituição Federal, as normas definidoras de direitos e garantias fundamentais têm aplicação imediata, disposição que, segundo a melhor interpretação sistemática e teleológica, abarca todas as normas de direitos fundamentais, estejam elas situadas no Título II (arts. $5^{\circ}$ a 17), estejam elas sediadas em outras partes da Constituição, de modo expresso ou implícito.

1 Tavares (2005, p.217-358), apresentando uma teoria funcionalista da Justiça Constitucional, identifica cinco grandes funções, que lhe são ínsitas: a) interpretativa, partindo a constatação de que a Constituição, a exemplo das leis em geral, não hospeda a solução total, objetiva e definitiva para as controvérsias sociais e jurídicas, tornando indispensável a intermediação judicial para a finalização da representação jurídica, com o que assume um papel nitidamente criativo de participação no processo de produção do direito; b) estruturante, atinente à promoção, adequação e harmonização formais do ordenamento jurídico, conforme sua lógica interna e seus próprios comandos relacionados à estrutura normativa adotada, buscando, em suma, a preservação da higidez da estrutura básica do edifício jurídico, o que inclui a tradicional tarefa de controle de constitucionalidade das leis; c) arbitral, que realiza o acertamento dos conflitos do sistema, notadamente quanto a conflitos de competência, envolvendo conflitos entre Poderes, proteção de minorias políticas, conflitos entre o próprio Tribunal Constitucional e outros Poderes, controle dos partidos políticos e o conflito entre entidades territoriais autônomas, tanto no plano normativo, como no plano material (controle federativo); d) legislativa, correspondente ao desenvolvimento de atividade geradora da composição inaugural de comandos com efeitos de caráter geral; e) governativa, que, com marcante caráter político, está atrelada à direção do Estado e à persecução dos seus fins. 
Considerando-se que todas as normas constitucionais são, em alguma medida, eficazes e, na medida de sua eficácia, aplicáveis, impõe-se compreender que o $\$ 1^{\circ}$, do art. $5^{\circ}$, da Constituição Federal, ao proclamar a aplicabilidade imediata das normas definidoras de direitos fundamentais, tem o sentido de que tais normas devem alcançar, de imediato, a plenitude da sua eficácia, e, consequentemente, da sua aplicabilidade (VIANNA, 2013, p.144-145), tratando-se, no dizer de ENTERRIA (2006, p.73), de um plus normativo a reforçar a eficácia das normas definidoras de direitos fundamentais. Contudo, é imprescindível ressalvar que, também na esfera dos direitos fundamentais há normas que, por não positivadas com suficiente densidade normativa, não se encontram em condições de, independentemente de mediação concretizadora, gerar a plenitude dos seus efeitos (SARLET, 2009, p.270). Força concluir, pois, que o preceito constitucional em tela não tem, de per si, o condão de conferir, de imediato, em todos os casos, plena eficácia e aplicabilidade, bem como efetividade, a toda norma de direitos fundamentais. Mas, se, por si só, não assegura a plena aplicabilidade imediata de todas as normas definidoras de direitos fundamentais, certo é que vincula o Estado à adoção de todas as medidas necessárias a promover e a assegurar tal aplicabilidade, dando azo a que nele se vislumbre, além da regra da aplicabilidade imediata dos das normas definidoras de direitos fundamentais, uma norma de cunho principiológico, constituindose num mandado de otimização ou maximização, impositivo aos órgãos estatais da tarefa de reconhecerem e promoverem a maior eficácia possível aos direitos fundamentais. Destarte, gera uma presunção favorável à aplicabilidade imediata das normas definidoras de direitos e garantias fundamentais, cuja eventual recusa, por ausência de ato concretizador, há de ser devidamente fundamentada. Assim, a aplicabilidade imediata e a eficácia plena das normas de direitos fundamentais constituem regra geral, ressalvadas exceções devidamente motivadas à luz do caso concreto (SARLET, 2009, p.270-271).

Nesse contexto, o grau de eficácia dos direitos fundamentais, pressuposto de sua efetividade, depende fundamentalmente de dois fatores: a técnica de positivação das normas de direitos fundamentais, notadamente no que tange à sua densidade normativa, e a função que exercem (SARLET, 2009, p.273-274). Com efeito, sabese que os direitos fundamentais podem ser divididos em dois grandes grupos: a) os chamados direitos de defesa, abrangendo os direitos de liberdade, igualdade, as garantias, liberdades sociais e os direitos políticos; b) e os chamados direitos a prestações, abarcando tanto direitos a prestações em sentido amplo, tais como os direitos à proteção e à participação na organização e no procedimento, como direitos a prestações em sentido estrito, representados pelos direitos sociais de natureza prestacional (SARLET, 2009, p.260).

Especialmente na seara dos direitos fundamentais prestacionais (ou função prestacional dos direitos fundamentais) cuida-se de direitos a ações positivas do Estado, encontrando grande limitador à sua realização na chamada reserva 
do possível, abrangente dos limites fáticos (escassez de recursos) e jurídicos (disponibilidade orçamentária) à sua efetivação. Além disso, os direitos prestacionais têm extremamente dificultada a sua configuração como direitos subjetivos (portanto exigíveis), na medida em que, justamente por dependerem de circunstâncias socioeconômicas, tendem a ser positivados de forma vaga e aberta, geralmente sob as modalidade de normas-tarefa, normas-programa, normas-fim e imposições legiferantes, deixando ao legislador infraconstitucional uma considerável margem de liberdade na tarefa concretizadora (SARLET, 2009, p. 260-262, 286, 287, 289, 291 292), que não implica, no entanto, absoluta discricionariedade, na medida em que o elaborador da lei está sujeito ao balizamento dos princípios e objetivos traçados pela Constituição, sem prejuízo de sua subjetivação.

É justamente este último aspecto, relativo à (in) suficiência normativa para a implementação dos direitos fundamentais, que diz diretamente com o foco do presente estudo, na medida em que constitui condição relevante para a eficácia, e consequentemente, para a efetividade dos direitos consagrados com primazia pela Constituição Federal.

No caso brasileiro, a Constituição Federal de 1988 claramente aponta para a conformação de um Estado Social de Direito, o que se reflete diretamente na expressa e destacada consagração dos direitos sociais, ao lado das liberdades e garantias individuais, como direitos fundamentais. A Constituição brasileira nitidamente determina a busca de uma igualdade substancial, não se contentando com a mera igualdade formal própria do Estado Liberal clássico.

Daí porque, a análise do enfrentamento da omissão normativa inconstitucional pelo Tribunal Constitucional brasileiro aqui empreendida parte da constatação de que o mandado de otimização extraído do $\$ 1^{\circ}$, do art. $5^{\circ}$, da Constituição Federal, é determinante do reconhecimento de um direito subjetivo público à edição de regulamentação necessária ao exercício de direitos fundamentais que, por exceção, dela careçam (VIANNA, 2013, p.290).

\section{A Omissão Normativa Inconstitucional como Óbice à Eficácia e à Efetividade dos Direitos Fundamentais}

Nada pode ser mais atentatório aos direitos fundamentais, no seio de um Estado Democrático e Social de Direito, do que a omissão estatal, quer no que tange à implementação de políticas públicas concretizadoras do programa constitucional, quer no tocante à normatização necessária à plenitude da eficácia e, consequentemente, à efetividade de tais direitos. 
Uma omissão constitucionalmente relevante, como leciona MIRANDA (2005, p.292), verifica-se sempre que, mandando a norma constitucional reguladora de certa relação ou situação praticar determinado ato ou atividade, sob determinadas condições, "o destinatário não o faça, não o faça nos termos exigidos, não o faça em tempo útil, e a esse comportamento se liguem consequências mais ou menos adequadas".

O dever de ação constitucionalmente determinado envolve todas as funções emanadas do poder do Estado e vincula, consequentemente, todos os órgãos constitucionais, que compartilham os respectivos exercícios, segundo o complexo de competências traçado pela Lei Maior. O problema da omissão inconstitucional abrange, portanto, tanto omissões de atos normativos, diretamente relacionados ao objeto do presente estudo, como de atos de conteúdo individual e concreto (MIRANDA, 2005, p.292). Destarte pode ser politica ou governamental, quando se refere à falta de decisão política, de adoção de uma política pública, ou, mais amplamente, à omissão de quaisquer atos políticos ou de governo; administrativa, quando diz respeito à falta de ato ou providência administrativa, podendo envolver a omissão de atos de execução de leis, ou de decisões judiciais, ou, ainda, a omissão do poder regulamentar do executivo; jurisdicional, quando consistente na negativa de prestação jurisdicional pelo órgão a tanto competente; ou legislativa, que, como enfatiza MENDES (2011, P.1295), pressupõe um dever constitucional de legislar, resultante tanto de comandos constitucionais explícitos, como de decisões fundamentais da Constituição identificadas no processo de interpretação. Nesta hipótese, destaca CANOTILHO (1994, p.331), "o legislador não faz algo que lhe era positivamente imposto pela Constituição", não se tratando de "um simples negativo não fažer, mas, sim, de não fazer aquilo a que de forma concreta estava obrigado".

Abordar-se-á, doravante, a omissão normativa inconstitucional, tomada assim em termos amplos, para abranger, tanto a omissão legislativa inconstitucional em sentido estrito, como a omissão administrativa regulamentar, isto é, para enfocar o descumprimento do dever de emitir atos normativos primários e secundários, necessários à integração e concretização do ordenamento constitucional, sempre enfatizando especialmente que a omissão dos poderes competentes em dotar direitos fundamentais de densidade normativa bastante à plenitude da sua eficácia é flagrantemente anticonstitucional, caracterizando-se como manifesta insuficiência no cumprimento do dever de proteção do Estado em relação a esses direitos.

Considerando-se a existência de lacunas técnicas, ou de legislação, constitutivas de uma esfera de liberdade de conformação deliberadamente reservada pelo constituinte ao legislador infraconstitucional, a aferição de uma omissão constitucionalmente relevante decorrente da violação de certa e determinada norma constitucional, não exequível por si mesma, de cunho prescritivo, e não meramente permissivo, em razão da falta, ou deficiência, das medidas normativas 
necessárias para torná-la exequível (MIRANDA, 2005, p.305 e 312) envolve o exame do tempo em que deveria ser produzida a norma, não se podendo descrever uma omissão em abstrato, mas somente em concreto, mediante balizamento entre determinados eventos, estes de sinal positivo. A aferição deste tempo, quando não constitucionalmente prefixado, dependerá da natureza das coisas, notadamente da norma constitucional carente de concretização, em confronto com as situações da vida enfocadas. Assim, o órgão de fiscalização deverá concluir pela omissão sempre que reconhecer que o legislador não só poderia como deveria ter emitido a norma reclamada, diante das circunstâncias em que se colocou ou foi colocado, residindo, o significado último da omissão inconstitucional, no afastamento por omissão, por parte do legislador, dos critérios e valores da norma constitucional que demanda regulamentação. E "este afastamento só pode ser reconhecido no tempo concreto em que um e outro se movam” (MIRANDA, 2005, p.309-310).

Tal omissão pode ser total, quando o órgão competente não empreende a providência legislativa reclamada, ou parcial, quando o faz de modo insuficiente à realização da vontade constitucional. Outrossim, a omissão é dita absoluta quando consistente no descumprimento de um dever autônomo de emanação normativa, ou relativa, quando, independentemente da existência de um dever constitucional de editar norma, o órgão competente o faz, mas com violação ao princípio da isonomia, seja pela falta involuntária de extensão de benefício a determinados grupos ou categorias, seja por arbitrária exclusão de determinados grupos de vantagens legais, hipótese última esta em que, na realidade, não há propriamente uma omissão, mas, sim, um ato positivo, um "fazer anulável” (CANOTILHO, 1994, p.334).

A omissão normativa inconstitucional também pode restar configurada na hipótese de inertia deliberandi. Embora a Constituição, de modo geral, não fixe prazo para a deliberação legislativa do Congresso, a inertia deliberandi resta caracterizada em caso de conduta manifestamente negligente ou desidiosa das Casas Legislativas, de modo a por em risco a própria ordem constitucional. Embora a Jurisprudência do STF se posicionasse, inicialmente, no sentido de que, desencadeado o processo legislativo, não há cogitar-se de omissão inconstitucional, já há precedente de reconhecimento de mora legislativa por inertia deliberandi, com fixação de prazo para a deliberação das Casas Legislativas².

Mesmo não consistindo estritamente na ausência total ou parcial de norma, pode ser apontada como outra espécie de omissão normativa constitucionalmente relevante, ainda, a omissão, ou deficiência, de prognose, decorrente, como frisa BERNARDES (2004, p.224), do caráter permanente do dever de implementação da aplicabilidade das normas constitucionais, que sujeita a constitucionalidade da medida normativa editada a uma espécie de cláusula rebus sic stantibus.

2 Nesse sentido: ADI 3.682, Rel.Min.Gilmar Ferreira Mendes, julgamento 09.05.2007. 
Em todas as hipóteses configuradoras das diversas espécies de omissões normativas constitucionalmente relevantes, o que mais importa ter presente é que, como acentua BARROSO (2003, p.161), "se um ato, mesmo omissivo, impede o exercício de um direito constitucionalmente previsto, na verdade o está violando, e, portanto, esta não é uma questão estritamente política", relevando acrescentar que, na seara dos direitos fundamentais, especialmente no tocante às normas atributivas de direitos, a existência de atos estritamente políticos tem importância restrita, na medida em que, se afetarem direitos subjetivos, desnaturam-se, ensejando controle jurisdicional, consoante art. $5^{\circ}$, XXXV, da Constituição Federal (BARROSO, 2003, p.88).

Daí porque o Supremo Tribunal Federal, como Tribunal Constitucional, assim caracterizado por receber da Constituição Federal um complexo de competências ínsitas à Justiça Constitucional, no âmbito de sua missão precípua de guarda da Constituição (CF, art.102, caput), tem como tarefa primordial, na tutela dos direitos fundamentais, o enfrentamento da omissão inconstitucional, inclusive àquela de cunho normativo, aqui enfocada.

\section{A Necessária Superação da Fórmula do "Legislador Negativo"}

Para o enfrentamento da omissão normativa inconstitucional, impõe-se afirmar que o STF, como autêntico órgão de Justiça Constitucional, necessariamente há de exercer uma função de natureza normativa em sentido amplo, ou mesmo materialmente legislativa em sentido estrito e, portanto, positivo, tornandose imperiosa a superação da tese Kelseniana do Tribunal Constitucional como "legislador negativo".

KELSEN (1999, p.37), ao sustentar o controle jurisdicional abstrato de legitimidade constitucional das leis, consagrou a fórmula do Tribunal Constitucional como "legislador negativo", aduzindo que anular uma lei é ditar uma norma geral, porque a anulação de uma lei tem o mesmo caráter de generalidade que a sua produção, não sendo senão uma produção com sinal negativo e, assim, uma função legislativa. Sob tal fórmula, as decisões proferidas em sede de controle abstrato de constitucionalidade das leis restam limitadas ao binômio constitucionalidade/ invalidade, ficando a atuação da Justiça Constitucional reduzida, segundo as palavras de DIAS (2010, p.94), a uma perspectiva minimalista de "jardineiro fiel do ordenamento jurídico", para eliminar "ervas daninhas" surgidas no campo constitucional, já semeado pelo legislador constitucional competente.

3 A expressão já fora utilizada por Jeremy Bentham no escrito de 1776 intitulado A fragment of government. (DIMOULIS; LUNARDI, 2010, p.167). 
Sabidamente são muitas as críticas à ideia do Tribunal Constitucional como "legislador negativo", principiando pela contestação da própria natureza legislativa atribuída por KELSEN à anulação de enunciado legislativo tido como inconstitucional em sede de controle abstrato de constitucionalidade. Nessa perspectiva, TAVARES (2009, p.171), embora reconheça a natureza normativa do controle abstrato de constitucionalidade das leis, que enquadra como função estruturante da Justiça Constitucional, nega-lhe a natureza legislativa em sentido estrito, entendida como "O desenvolvimento de atividade da qual resulta a composição inaugural de comandos com elementos de caráter geral". Para além disso, atribui-lhe status constitucional e, portanto, supralegal, sob o argumento de que a eliminação de dispositivos legais incompatíveis com a Constituição assenta em base exclusivamente constitucional, sendo o conflito entre fontes do direito de estatura diferenciada resolvido por ato de estatura idêntica ao do ato hierarquicamente superior violado. Assim, a integridade normativa da Constituição é recomposta por ato que se deve considerar de mesma hierarquia da Constituição e não do ato infraconstitucional violador (TAVARES, 2009, p.173).

DIMOULIS e LUNARDI (2010, p.176-177), partindo da concepção de função legislativa como criação de normas jurídicas gerais e abstratas, no intuito de regulamentar determinadas relações ou situações, vinculando os demais órgãos estatais, enfatizam que a função de controle de constitucionalidade das leis não tem o intuito de regulamentar algo, faltando-lhe vontade legislativa, ao que se alia o caráter técnico de verificação da regularidade da função normativa segundo a constituição, razão pela qual esposam o entendimento doutrinário majoritário, atribuindo natureza tipicamente jurisdicional à função analisada.

Nesse ponto, não se pode deixar de notar que mesmo KELSEN (2003, p.153) reconheceu expressamente a natureza jurisdicional da função desempenhada por aquele que designou como "legislador negativo". Versando sobre a organização da Jurisdição Constitucional e ressalvando que todas as questões políticas que dominam a questão da formação do órgão legislativo não entram em conta quando se trata da anulação de leis, estabelece uma distinção entre a elaboração e a anulação de leis. Nesta, que se produz essencialmente como aplicação das normas da Constituição, a atividade criativa característica da legislação está quase totalmente ausente, sendo a atividade do legislador negativo determinada pela Constituição, ao passo que, naquela, o legislador tem ampla liberdade de criação, estando preso à Constituição somente no que tange ao procedimento e, quanto ao conteúdo, a princípios ou diretivas gerais. Assim, conclui que é precisamente com base nisso que a função do Tribunal Constitucional se assemelha a de qualquer outro Tribunal: "ela é principalmente aplicação e somente em pequena medida criação do direito. É, por conseguinte, efetivamente jurisdicional". Tem-se, então, que a diferença entre as atividades do legislador e do "legislador negativo" residiria, para KELSEN, na amplitude da liberdade de criação, maior para o primeiro e sensivelmente reduzida 
para o segundo, visto que o Mestre de Viena, fiel à concepção de uma estrutura escalonada de normas, expressamente rechaça uma oposição entre criação e aplicação do direito, enfatizando que todo ato jurídico é, simultaneamente, aplicação de uma norma superior e criação de uma norma inferior (KELSEN, 1991, p.252-253).

Para além da discussão travada em torno da natureza da função de controle abstrato de constitucionalidade das leis, sobreleva a manifesta insuficiência da fórmula do "legislador negativo" frente ao acúmulo e à crescente complexidade das funções assumidas pela Justiça Constitucional na guarda da Constituição, no seio do Estado Social de Direito. Com efeito, na passagem do Estado Liberal, para o Estado Social de Direito, sobretudo no segundo pós-guerra, com o advento do Constitucionalismo Social tomando espaço do Clássico Constitucionalismo restrito a declarações de direitos individuais e à organização do Estado ancorada na "separação dos poderes", as constituições ditas sintéticas passam a ceder lugar a constituições analíticas, de cunho dirigente, com extenso catálogo de direitos fundamentais, inclusive sociais, como no caso da Constituição Brasileira de 1988, e uma multiplicidade de normas-fim, que demandam uma postura marcadamente ativa do Estado, para a concretização do programa constitucional.

Nesse contexto, como salienta SEGADO (2003, p.251), diversos fatores, dentre os quais o princípio da conservação da norma frente às exigências decorrentes do princípio da segurança jurídica, a multiplicação de leis a partir dos extensos textos constitucionais, a natureza objetiva dos direitos fundamentais a demandar interpretação como uma ordem objetiva de valores, a grande relevância assumida pelo princípio da igualdade, em suas vertentes material e formal, os graves problemas e o vazio normativo que podem decorrer de sentenças pura e simplesmente declaratórias de inconstitucionalidade, tornam imperiosa a busca de fórmulas mais flexíveis do que a dicotomia validade/nulidade, o que explica, segundo as palavras do autor, "esta função positiva que hoje vêm assumindo com toda a naturalidade os Tribunais Constitucionais”.

A tese da nulidade absoluta ${ }^{4}$ da lei tida como incompatível com a Constituição, que de fato já produziu efeitos indeléveis, em muitos casos mostrou-se capaz de gerar consequências econômico-sociais e políticas muito mais gravosas do que a sua própria ilegitimidade Constitucional. Ademais, frente à omissão inconstitucional total não se reveste de nenhuma utilidade, sequer comportando aplicação, porquanto concebida exclusivamente para o enfrentamento da inconstitucionalidade por ação. Já no tocante ao trato da omissão relativa, revela-se potencialmente geradora de inconstitucionalidade maior, convolando omissão parcial em omissão total.

4 É sempre importante ressalvar que a tese da nulidade absoluta, embora tenha prevalecido na jurisprudência constitucional aplicadora da fórmula do "legislador negativo", não pode ser atribuída a KELSEN (2003, p.139-148), que, ao revés, atentando para os efeitos já gerados pela norma e para os riscos decorrentes do vazio normativo, refutou-a, advogando a tese da anulabilidade da lei inconstitucional, com eficácia "ex nunc", diferida, ou mesmo, se cabível a Juízo do Tribunal Constitucional, retroativa.. 
Irretocável, pois, a observação de CANOTILHO (2003, p.1006) no sentido de que a inconstitucionalidade por omissão é um instituto que reflete as insuficiências resultantes da redução do Estado de direito democrático aos processos e instrumentos típicos dos ordenamentos liberais.

Destarte, premida pelas necessidades inerentes ao constitucionalismo contemporâneo, a jurisprudência constitucional desenvolveu novas técnicas de decisão, comumente chamadas flexíveis, atípicas ou alternativas, como a interpretação conforme a constituição e as ditas sentenças interpretativas ou manipulativas, sejam aditivas, redutoras ou substitutivas, ganhando relevo, também, notadamente no caso brasileiro, a previsão constitucional de ações específicas para o enfrentamento da omissão inconstitucional , que adiante serão abordadas.

MEDEIROS (1999, p.494), a despeito de sua visão restritiva acerca das novéis técnicas decisórias da Justiça Constitucional, não deixa de fazer eloquente relato acerca da tendência de assunção de uma postura ativa da Justiça Constitucional frente às exigências do Constitucionalismo no Estado Social de Direito:

Se na época liberal bastava cassar a lei, no período do Estado Social, em que se reconhece que a própria omissão de medidas soberanas pode pôr em causa o ordenamento constitucional, torna-se necessário a intervenção activa do Tribunal Constitucional. A reivindicação de um papel positivo para o Tribunal Constitucional é um corolário da falência do Estado Liberal. Efectivamente, enquanto para eliminar um limite normativo (v.g. uma proibição ou um ônus) e restabelecer plenamente uma liberdade, basta invalidar a norma em causa, o mesmo não se pode dizer quando se trata de afastar uma omissão legislativa inconstitucional. Neste segundo caso, se seguir o modelo clássico de justiça constitucional, a capacidade de intervenção do juiz das leis será muito reduzida. Urge, por isso, criar um sistema de justiça constitucional adequado ao moderno Estado Social. Numa palavra: a configuração actual das constituições não permite qualquer veleidade aos tribunais constitucionais em actuarem de forma meramente negativa, antes lhes exige uma esforçada actividade que muitas vezes se pode confundir com um indirižo político na efectiva concretização e desenvolvimento do programa constitucional. Daí o falhanço de todas as teses que pertendiam arrumar os tribunais constitucionais numa atitude meramente contemplativa perante as tarefas constitucionais e o esbatimento, claro em Itália, dos limites à admissibilidade de decisões modificativas.

Daí a reiterada crítica ao déficit processual da fórmula do "legislador negativo", por ignorar a multiplicidade de técnicas decisórias empregadas pela Justiça Constitucional, que suplantam a mera cassação da norma tida como inconstitucional. Em verdade, tais técnicas decisórias, supervenientes à tese de KELSEN, constituem nítido efeito e pura expressão da insuficiência da fórmula do legislador negativo. 
A tais críticas, ainda na senda de uma atuação positiva da Justiça Constitucional, DIAS (2010, p.111) acresce o déficit interpretativo da fórmula do legislador negativo, encobridora da inevitável tarefa interpretativa da Corte Constitucional, que manipulando o texto constitucional em abstrato, para aplicação ao caso concreto, exorbita a tarefa minimalista de verificação formal dos seus requisitos de validade, para proceder a sua eventual cassação, atuando como verdadeiro criador originário de normas, muitas vezes para além dos limites previamente postos pelo legislador.

\section{A Legitimidade da Atuação Normativa em Sentido Positivo do STF}

Contudo, não se faz bastante afirmar a insuficiência e a necessidade de superação da fórmula do "legislador negativo". Impõe-se perquirir se e como se legitima uma atuação normativa em sentido positivo por parte da Justiça Constitucional.

Nesse passo, agudizam-se os grandes óbices opostos à própria existência da Justiça Constitucional, que ainda se mostram fortemente presentes no debate quanto aos limites da sua atuação, quais sejam, a clássica ideia de "separação dos poderes" e, correlato ao primeiro, o princípio democrático calcado na concepção liberal de democracia representativa, que reservaria as decisões políticas (aí incluída a atividade legislativa) aos representantes eleitos pelo povo. São questões que, embora merecedoras de estudo específico, dada a sua complexidade, não podem deixar de ser aqui referidas, ainda que em apertadíssima síntese.

Em primeiro lugar, a imprescindível atuação da Justiça Constitucional pela efetivação dos direitos fundamentais não deve restar refém de uma ficção batizada, há mais de dois séculos, como "separação de poderes". Sendo uno o Poder Estatal, expressão da soberania do Estado, o que se convencionou chamar como "separação de poderes" é, na verdade, uma distribuição mais ou menos rígida, conforme cada ordem constitucional, de funções estatais entre órgãos do Estado ${ }^{5}$. Nada mais é, portanto, do que uma repartição de competências determinada pelo direito positivo em nível constitucional. Assim, a simples alusão à "separação de poderes", tantas vezes invocada como óbice à atuação normativa do Tribunal não guarda, em si, um sentido inteligível, na medida em que não corresponde a um só e determinado arranjo institucional, cabendo à Constituição de cada País, por meio da atribuição de competências, delinear a arquitetura jurídico-institucional da repartição e do compartilhamento do exercício das funções do Estado, sob inevitável influxo das

5 Bem esclarece CANOTILHO (2003, p.551) que "quando se fala de repartição ou separação de poderes o que, em rigor, se recorta em termos de repartição ou separação é a atividade do Estado e não o poder do Estado. O resultado desta divisão não é a existência de vários poderes, mas a existência de funções diferenciadas". No mesmo sentido, LOEWENSTEIN (1976, p.55). 
culturas políticas que as animam, o que leva a um processo dinâmico de interação entre os órgãos constitucionais, mutável no tempo e no espaço (VIANNA, 2013, p.296).

E tal arquitetura jurídico-institucional, no seio do Estado Constitucional contemporâneo, não mais pode ser compreendida como concebida em sua gênese, no nascedouro do Estado Liberal Moderno, em que tinha por missão precípua dividir para limitar, sob a conclusão de que somente o poder é capaz de deter o poder, objetivando exclusivamente a proteção da liberdade individual e, sobretudo, da propriedade privada frente aos riscos representados pelo grande "leviatã", aprisionado aos lindes do direito público, desde a queda do Absolutismo. Superado o dogma de clareza, completude e coerência da lei, que assegurava amplo espaço à atuação da autonomia da vontade, e afirmadas a supremacia e a força normativa da Constituição, a marca da repartição funcional do poder no Estado Constitucional Social contemporâneo é a complexidade. Exige-se uma postura ativa do Estado, na concretização do programa Constitucional. Já não se faz bastante a frenagem do poder pelo poder. A ideia de divisão, ou separação, cede espaço ao compartilhamento de funções entre órgãos estatais - e mesmo não estatais - e à multifuncionalidade de cada órgão, a bem de um controle recíproco e de um profícuo diálogo institucional, imprescindível à democracia constitucional.

Não é diferente a situação no tocante à atividade legislativa, em cujo exercício se verifica, notadamente na realidade pátria, inclusive uma nítida preponderância da Chefia de Governo, não só pelos elementos formais da iniciativa e do veto, mas, sobretudo, pela formação de uma sólida maioria congressual, que prioriza ou pretere matérias, delibera, ou não delibera, segundo os ditames governamentais.

Imprescindível acrescentar que também o Tribunal Constitucional compartilha do exercício da direção política do Estado, instrumentalizada pela atividade legislativa, não só no sentido negativo do controle de legitimidade constitucional dos atos emanados dos demais órgãos constitucionais, como no sentido positivo do enfrentamento das omissões estatais no cumprimento dos seus deveres de proteção, inclusive e destacadamente, no cumprimento do dever de atuação normativa (VIANNA, 2013, p.296).

Nesse contexto, definitivamente rompidas as amarras do mito montesquiano da neutralidade judicial, a Justiça Constitucional exsurge como importantíssima partícipe do exercício do Poder Estatal. Acima de tudo, urge a consolidação da perfeita compreensão de que não pode haver maior e mais patológica hipertrofia do exercício de competências constitucionais por um órgão estatal, seja ele qual for, do que permitir-se-lhe arrogar-se o "poder" de recusar-se a fazer o que a constituição manda, e o pior, fazê-lo de modo a esvaziar a eficácia jurídica e, consequentemente, a inviabilizar a efetividade dos direitos fundamentais que constituem a razão maior de ser e o norte de uma Carta Constitucional dirigente como a brasileira de 1988. 
Daí merecer primazia o enfrentamento da omissão inconstitucional, que somente se realiza eficazmente mediante uma atuação normativa da Justiça Constitucional, inclusive, quando necessário, em sentido positivo.

De superar-se, igualmente, o recorrente questionamento da legitimidade democrática da Justiça Constitucional, sobretudo no que pertine à sua atuação normativa em sentido positivo. Democracia é uma expressão plurívoca, não existindo um modelo absoluto a ser considerado, embora suas diversas acepções convirjam, de modo geral, para a ideia de governo representativo da vontade do povo. Daí a grande resistência a admitir-se que órgãos democraticamente eleitos pelo povo tenham as suas decisões contestadas e mesmo invalidadas, ou as suas esferas de competência invadidas, por um órgão não eleito, configurando uma natural repulsa ao que LAMBERT (1921) qualificou como "governo dos Juízes".

Contudo, não se deve reduzir a democracia ao princípio majoritário, tampouco à representação eletiva. Como observou HÄBERLE (2002, p.39), são muitas as formas de legitimação democrática, desde que se liberte de um modo linear de pensar acerca da concepção tradicional de democracia. E efetivamente a Justiça Constitucional se legitima democraticamente sob diversos aspectos, a principiar pelo fato de ser investida de num conjunto de competências outorgado pelo poder constituinte emanado do povo. Como bem destaca TAVARES (2005, p.499), no Estado Constitucional de Direito, a maioria momentânea deve curvar-se à vontade da maioria constituinte, acrescentando que:

É na Constituição que se dividem os poderes do Estado, o que só pode ser levado a efeito por um poder que lhes seja superior, e que é o poder constituinte originário. Nessa medida, todos os "poderes" são democráticos, já que procedem de um mesmo ato de soberania popular, que é a aprovação de uma específica ordem constitucional, e isso independentemente da estrutura final que se crie entre esses poderes.

Voltando o olhar à realidade pátria, verifica-se que o STF retira da ordem constitucional fundamentos institucionais, processuais e substantivos a legitimar a sua atuação normativa. Legitima-se institucionalmente, na medida em que, além de receber da própria Constituição um complexo de competências para interagir com os órgãos eleitos pela maioria de cada momento, reveste-se, ele próprio, ao menos indiretamente, de legitimidade político-representativa, porquanto composto por membros indicados pelo Presidente da República, eleito pelo voto direto, com a chancela do Senado, igualmente consagrado pelas urnas. Processualmente, legitimase sobretudo pela abertura do processo constitucional, que assim se constitui em importante foro para o debate público, dando voz, não só aos demais órgãos constitucionais, como aos principais atores sociais envolvidos, no sentido de uma autêntica e democrática "sociedade aberta dos intérpretes da constituição", a partir 
do que se converte, inclusive, em alguma medida, em instrumento de realização da democracia direta, que não conflita com, mas complementa a democracia representativa. A isso se somam a publicidade, o caráter técnico e a necessária motivação das suas decisões, a viabilizar o controle da sua atuação pelos demais órgãos constitucionais e pela sociedade em geral. Substantivamente, legitimase na medida em que atua precipuamente a bem da eficácia e da efetividade dos direitos fundamentais, cuja concretização constitui, a um só tempo, condição de viabilidade do processo democrático e objetivo maior da própria democracia no Estado Democrático de Direito, no que se destaca a tutela dos direitos das minorias, evitando eventual tirania flagrantemente anticonstitucional de maiorias conjunturais (VIANNA, 2013, p.297).

Releva acrescer a importante distinção destacada por ENTERRIA (2006, p. 180-184), citando BACHOF, entre as atividades do juiz ordinário e do juiz constitucional, demonstrando que aquele trata de um conflito entre a fidelidade à lei e a justiça do caso concreto, da justiça individual em face da lei, ao passo que este se depara com o enfrentamento entre o rigor da norma e as exigências do bem comum. Muitas vezes, as decisões do juiz constitucional têm efeitos vinculantes gerais, podendo ocasionar catástrofes não só para o caso concreto, como para uma multiplicidade de casos, quando tais decisões são "politicamente inexatas ou falsas". Daí porque o juiz constitucional, mais do que qualquer outro, não deve perder de vista as consequências - e frequentemente são consequências políticas - das suas decisões. O Direito Público não pode ser aplicado sem considerações políticas e os seus conceitos não podem ser interpretados sem recorrer a ideias ou convicções sociais e políticas da comunidade. Mas isso é próprio do método jurídico e não uma ruptura ou uma instrumentalização do mesmo. Embora o juiz constitucional não possa ser cego às consequências políticas de suas decisões, só pode levá-las em conta na medida das possibilidades abertas pelo ordenamento jurídico, não the sendo dado recusar validade à lei, tampouco integrar as lacunas legais, somente por considerações políticas, mas, sim, à luz de princípios jurídicos fundamentais, vale dizer, com base em direito de nível superior ${ }^{6}$.

Impõe-se atentar, também, para a manifesta imperfeição do sistema representativo, que põe em relevo a função maior de preservação da ordem constitucional frente aos riscos representados por maiorias ocasionais, bem ilustrados por SHAPIRO (1966, p.24):

O que realmente emerge da análise do Congresso e da Presidência não é o simples retrato de organismos democráticos e majoritários, que dão voz à vontade popular e são responsáveis perante ela, mas antes a complexa estrutura política na qual grupos variados procuram vantagem, manobrando entre vários centros de poder. O que daí

6 No mesmo sentido, FIX-ZAMUDIO (2003, p.87). 
resulta não é necessariamente a enunciação da vontade da maioria [...], e sim, frequentemente, o compromisso entre grupos com interesses conflitantes.

Destarte, assiste razão a ENTERRIA (2006, p.186) quando afirma que uma constituição sem uma Justiça Constitucional que imponha a sua interpretação e a sua efetividade, é uma constituição ferida de morte, que entrega a sua sorte à do partido detentor do poder, que impõe, por simples prevalência fática, a interpretação que nesse momento lhe convém, de modo que a Constituição passa a ser instrumentalizada por uns grupos ou partidos contra outros, provocando uma fratura do consenso básico que a Constituição deve assegurar.

Para além de tudo isso, importa notar que, convergindo as objeções à atuação normativa positiva da Justiça Constitucional com aquelas historicamente opostas à própria existência da jurisdição constitucional, é possível extrair mesmo da doutrina do ideólogo do "legislador negativo" fundamentos para a defesa do Tribunal Constitucional como "legislador positivo", tese, na verdade, não cogitada por KELSEN, que não versou sobre o enfrentamento da omissão inconstitucional, mas pelo mesmo também não refutada.

Vale ter presente, antes de tudo, o argumento central de KELSEN (1995, p.5), no seu embate com SCHMITT, no sentido de que a ninguém deve ser dado ser juiz de sua própria causa, perfeitamente aplicável, também, ao controle da inconstitucionalidade por omissão. Afinal, não se há de confiar o enfrentamento, sobretudo da mora legislativa, à discricionariedade do próprio órgão estatal moroso, o que se afigura tão grave, por ineficaz, quanto a elevação do poderoso Presidente do Reich à condição de guardião da Constituição, tão duramente criticada por KELSEN na doutrina de SCHMIT'T (2001).

KELSEN (2005, p.38) também é claro ao refutar a ideia de "separação de poderes", aduzindo que, se se quer manter o princípio na República democrática, só pode ser razoavelmente levado em consideração, dentre os seus diversos significados, aquele que melhor se expressa na forma de divisão de poderes, e não de separação dos mesmos, ou seja, o que alude à ideia de repartição do poder entre órgãos diferentes, não para isolá-los reciprocamente, mas para permitir o controle de uns sobre os outros, o que permite concluir que a instituição da Justiça Constitucional não está em contradição com o princípio, constituindo, ao revés, uma afirmação do mesmo.

KELSEN (2005, p.18,19 e 21) enfatiza, outrossim, que o processo de exercício do Poder não se esgota no Legislativo, tendo essencial continuação, ou mesmo efetiva iniciação, na jurisprudência e na Administração. Vendo-se a política como decisão na resolução de conflitos de interesses, conforme a terminologia de SCHMITT, então está presente, em maior ou menor medida, em toda a sentença 
judicial um elemento de decisão, vale dizer, um elemento de exercício do Poder, que muito mais se acentua das decisões do Tribunal Constitucional.

No positivismo Kelseniano, a competência do(s) órgão(s) legiferante(s) depende exclusivamente da organização posta pela Constituição, o que o leva a admitir que um Tribunal possa receber competência para criar normas gerais, e consequentemente, para legislar, já não aqui em sentido negativo, mas em sentido positivo:

Um tribunal, especialmente um tribunal de última instância, pode receber competência para criar, através de sua decisão, não só uma norma individual, apenas vinculante para o caso sub judice, mas também normas gerais. Isto é assim quando a decisão judicial cria o chamado precedente judicial, quer dizer: quando a decisão judicial do caso concreto é vinculante para a decisão de casos idênticos. Uma decisão judicial pode ter um tal caráter de precedente quando a norma individual por ela estabelecida não é predeterminada, quanto ao seu conteúdo, por uma norma geral criada por via legislativa ou consuetudinária, ou quando essa determinação não é unívoca e, por isso, permite diferentes possibilidades de interpretação. No primeiro caso, o Tribunal cria, com a sua decisão dotada de força de precedente, Direito material novo; no segundo caso, a interpretação contida na decisão assume o caráter de uma norma geral. Em ambos os casos, o tribunal que cria o precedente funciona como legislador, tal como o órgão a que a Constituição confere poder para legislar. (KELSEN, 1991, p.267)

Conclui, então, que, nesse caso, o Tribunal entra em concorrência com o órgão legislativo instituído pela Constituição, o que significa uma descentralização da função legislativa (KELSEN, 1991, p.268). Portanto, no pensamento positivista de KELSEN, não há, nem poderia haver, uma reserva natural de função à Casa Legislativa.

Coerentemente com esta linha de pensamento, $\operatorname{KELSEN}(1991$, p. 206) afirma que "apenas uma autoridade competente pode estabelecer normas válidas; e uma tal competência somente se pode apoiar sobre uma norma que confira poder para fixar normas". A partir disso, o questionamento sobre o cabimento, ou não, da atuação do STF como "legislador positivo" deve buscar resolução em uma questão anterior: a Constituição confere competência ao STF para criar normas gerais? À vista do rol de competências constitucionais outorgadas à Excelsa Corte brasileira, tem-se que a resposta ao questionamento retro deve ser afirmativa, tanto em sentido amplo, pela prolação de decisões com eficácia geral e efeito vinculante (CF, art.102, $\left.\$ 2^{\circ}\right)$, ou pelo poder de editar súmulas consolidadoras de entendimentos reiterados com efeito vinculante para os demais órgãos judiciários e da Administração direta e indireta (CF, art.103-A), que sempre importam criação do direito, como em sentido estrito, notadamente pela via do mandado de injunção, conforme a posição que 
aqui se adota, com a criação de direito ex novo, para integrar lacunas legislativas obstativas da efetividade de direitos fundamentais, segundo a interpretação que se extrai do art. $5^{\circ}$, LXXI, combinado com o art.102, I, q, do texto constitucional, à luz da função precípua de guarda da Constituição confiada ao STF (art.102, caput) e do mandamento de máxima eficácia e efetividade dos direitos fundamentais emanado do $\$ 1^{\circ}$, do art.5 $5^{\circ}$ da Lei Maior (VIANNA, 2013, p.222 e 293)

Mas, afirmando-se que ao STF deve ser dado legislar supletivamente, para integrar lacuna legal, de modo a assegurar efetividade de direitos fundamentais obstada pela recalcitrante carência de regulamentação, impõe-se indagar a quem incumbe o controle desta atividade legiferante pontual do próprio Tribunal. E a resposta necessariamente deve recair sobre o próprio "Poder" moroso, cuja competência se mantém intocada, facultando-lhe, a qualquer momento, emitir o diploma normativo até então omitido, em substituição à normatização provisória do Tribunal. Assim, se os legisladores não entenderem satisfatória a decisão do STF, basta que legislem para revogá-la como diploma normativo. Se, por outro lado, não o fizerem, autorizam subentender a sua satisfação em relação à solução dada pelo Tribunal. Portanto, a necessária atuação normativa em sentido positivo do STF de nenhum modo implica usurpação de competência do Parlamento, nem da Chefia de Governo.

Impende ter claro, ainda, que tal atuação, inclusive em sentido estrito, por meio de decisão com status de lei, não é potencialmente mais invasiva da esfera de competência dos demais órgãos constitucionais do que aquela caracterizada por KELSEN como de natureza legislativa em sentido negativo, no controle de constitucionalidade das leis, hoje pacificamente aceito, em que o Tribunal, por meio de decisão com status supralegal, simplesmente extirpa do ordenamento jurídico norma produzida mediante todo o desenrolar do processo legislativo, ou seja, diploma que passou, inclusive, pelos crivos preventivos de cunho político exercidos pelas comissões especializadas de ambas as Casas Legislativas e pela própria sanção presidencial.

\section{A Superação da Fórmula do Legislador Negativo no Processo Constitucional}

Patentes a insuficiência da fórmula do legislador negativo e a legitimidade da Justiça Constitucional para a sua superação, é mister empreender brevíssima, porém indispensável, abordagem, das técnicas de decisão e dos processos específicos de que lança mão a Justiça Constitucional, e mais especificamente o STF, no exercício da guarda da Constituição para muito além do controle restrito ao binômio constitucionalidade/nulidade da lei. 


\subsection{Das Técnicas ditas Atípicas de Decisáo}

Sob diferentes denominações, generalizaram-se, sob distintos matizes, determinados pelas características das diversas ordens constitucionais, as técnicas de decisão que têm sido chamadas de "atípicas", ou interpretativas em sentido amplo.

Como enfatiza DI MANNO (1997, p.126 e 129), o Juiz constitucional não pode exercer a sua delicada função de julgar a lei, mister de conteúdo acentuadamente político, de maneira puramente mecânica, razão pela qual a flexibilidade deve presidir o controle de constitucionalidade. Ademais, constitui tarefa primordial do Juiz constitucional conjugar todos os ramos do direito em torno de um conjunto de princípios comuns que têm lugar na constituição, para o que se exige o emprego de técnicas eficazes que permitam a difusão mais ampla e pacífica possível dos valores constitucionais em todos os ramos jurídicos. A técnica das decisões interpretativas contribui precisamente para responder a esta dupla exigência do controle de constitucionalidade, assumindo natureza multiforme, traduzida por um amplo leque de decisões e pela grande facilidade de adaptação, o que leva o autor a alcunhá-la como "técnica-camaleão", que muda de forma em razão da configuração das disposições legais e, acrescenta-se aqui, das lacunas legislativas, submetidas ao crivo da constitucionalidade.

Dentre tais técnicas de decisão, pode-se destacar, em primeiro lugar, a da interpretação conforme à constituição, conducente a decisão interpretativa em sentido estrito, que consiste em extrair dentre os diversos possíveis significados de um texto normativo, aquele que se afigure em conformidade com a constituição, ou, em outros termos, partindo da distinção entre enunciado normativo e norma, em escolher dentre as diversas normas possíveis aquela que se coadune com a Lei Maior, o que permite manter hígido o texto legal submetido ao crivo da constitucionalidade. Assim, o Tribunal deixa de declarar a inconstitucionalidade do enunciado normativo, desde que interpretado na forma indicada na motivação da decisão.

Por vezes, a interpretação conforme a constituição vai além da sua concepção estrita, de modo que o Tribunal, mediante atividade interpretativa, que como já enfatizava KELSEN, é também sempre criativa, "corrige" a norma em princípio exarada do enunciado normativo em xeque, de forma a conformá-la à Constituição, hipóteses em que se tem as chamadas decisões "corretivas", ou mesmo "substitutivas".

Muito próxima da técnica da interpretação conforme a Constituição está a da declaração de inconstitucionalidade parcial, sem redução de texto. Nesse caso, como explica CRISAFFULI (1984, p.402-403), uma mesma disposição exprime ou é suscetível de exprimir diversos significados normativos, que não são entre si 
alternativos, mas inclusivos.. É o caso, como exemplifica o autor, de uma disposição que diz "A", compreendendo a', a" e a", e somente um destes significados se afigura constitucionalmente ilegítimo. O Tribunal, então, restringe a declaração de inconstitucionalidade aos significados tidos como constitucionalmente ilegítimos, excluindo do campo de aplicação da norma determinadas hipóteses ou grupos, mas mantendo íntegro o texto legal. Portanto, enquanto na interpretação conforme o Tribunal aponta dentre as interpretações possíveis, alternativas entre si, aquela que se conforma ao ordenamento constitucional; na declaração de inconstitucionalidade parcial sem redução de texto, o Tribunal exclui as possibilidades de aplicação que conflitam com a constituição, mantendo as demais.

Ganham igualmente grande importância, sobretudo a partir da sua consagração na jurisprudência do Tribunal Constitucional italiano e principalmente na tutela da isonomia, as chamadas sentenças aditivas, que declaram a inconstitucionalidade da omissão de algo que deveria estar previsto na lei. Por vezes, tais omissões decorrem de exclusões ilegítimas, que, assim, devem ser afastadas, por inconstitucionais. Em outros casos, há pura e simplesmente uma omissão, abrindo lacuna legal que é colmatada mediante atividade interpretativa do Tribunal (CRISAFFULI, 1984, p.403404). Diferentemente da técnica de declaração de inconstitucionalidade parcial, sem redução de texto, na técnica de decisões aditivas, o texto legal não é censurado pelo que diz, mas pelo que omite. Naquela, restringe-se o campo de aplicação da norma; nesta estende-se o seu alcance, enriquecendo-se o conteúdo normativo da disposição legal, adicionando-lhe o que falta para estar em conformidade com a ordem Constitucional. Enquanto as técnicas de decisão anteriormente abordadas superam a fórmula do legislador negativo principalmente no enfrentamento da inconstitucionalidade por ação, as sentenças aditivas constituem importante instrumento de controle da omissão inconstitucional.

Notadamente da jurisprudência do Tribunal Constitucional Federal alemão, posteriormente acolhida pelas cortes constitucionais de diversos outros países, extraem-se as técnicas da declaração de incompatibilidade ou inconstitucionalidade, sem pronúncia de nulidade e do apelo ao legislador. A primeira encerra um juízo de desvalor em relação à norma questionada, obrigando o legislador, nos termos dos arts. $1^{\circ}$, III (vinculação dos órgãos estatais aos direitos fundamentais) e 20, III, da Lei Fundamental de Bonn (garantia do Estado de Direito e vinculação dos órgãos estatais aos princípios estabelecidos na Lei Fundamental), a empreender as medidas necessárias à supressão do estado de inconstitucionalidade. Lançando mão da segunda, o Tribunal Constitucional rejeita a arguição de inconstitucionalidade, sinalizando, entretanto, para uma possível conversão da situação "ainda constitucional" num estado de inconstitucionalidade, conclamando, então, o legislador, por vezes com expressa fixação de prazo, a atuar no sentido de corrigir ou adequar tal situação "ainda constitucional", de forma a prevenir uma futura inconstitucionalidade, proporcionando uma situação plenamente constitucional (MENDES, 2005, p.267-269 e 296). 
O STF tem utilizado a expressão "interpretação conforme à Constituição" em sentido amplo, para abranger todas as técnicas decisórias ora abordadas, o que se afigura mais palatável à cautelosa tradição de self restraint da Suprema Corte brasileira ${ }^{7}$. Claro exemplo disso é o recente e importante julgamento de ação direta de inconstitucionalidade ajuizada pelo Procurador Geral da República (ADI 4277DF) e de arguição de descumprimento de preceito fundamental proposta pelo Governador do Estado do Rio de Janeiro (ADPF 132-RJ), convertida em ação direta de inconstitucionalidade, em que o STF, segundo o voto prevalecente do relator, Ministro Ayres Britto, deu interpretação conforme à Constituição ao art.1723 do Código Civil para dele excluir qualquer significado que impeça o reconhecimento da união contínua, pública e duradoura entre pessoas do mesmo sexo como entidade familiar, entendida esta como sinônimo de família. Trata-se de nítida decisão de cunho aditivo, por meio da qual o Tribunal Constitucional brasileiro eliminou exclusão tida como inconstitucional, para estender o reconhecimento de união estável, na forma do art.1723 do Código Civil, às uniões homoafetivas não abarcadas pela literalidade do aludido dispositivo legal.

Impende mencionar, ainda, a possibilidade de modulação dos efeitos da decretação de inconstitucionalidade, positivada no direito brasileiro pelo art.27 da Lei n.9868/99, que, a bem da segurança jurídica ou de excepcional interesse social, prevenindo os efeitos danosos do vazio legislativo, permite ao STF atribuir à sua própria decisão eficácia pro futuro, desde a sua edição, ou a partir de momento fixado pelo Tribunal, como no caso da ADI 3682-MT, em que o Tribunal julgou procedente a ação para reconhecer a mora do Congresso Nacional no cumprimento

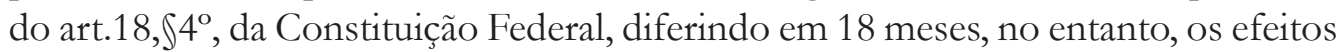
de tal decisão, para que as leis estaduais que criam municípios ou alteram seus limites territoriais continuassem vigendo, até que Lei Complementar viesse a disciplinar a matéria, problema que acabou solucionado com a edição da EC n.57/2008. Em outros casos, pode-se chegar ao extremo da declaração de inconstitucionalidade sem pronúncia de efeitos, como em relação às inúmeras ações intentadas contra a legislação fixadora do salário mínimo, que, por mais insuficiente que seja frente às exigências do art. $7^{\circ}$, IV, da Constituição Federal, não deve ser cassada, sob pena de criar-se vazio legislativo com efeitos muito mais gravosos.

O que aqui mais importa ter presente é que, em todas as técnicas de decisões interpretativas em sentido amplo, ora abordadas, resta patente o caráter criativo, e, portanto, normativo lato sensu. $\mathrm{O}$ mesmo se diga em relação à modulação dos efeitos da decretação ${ }^{8}$ de inconstitucionalidade, porquanto tem o condão de manter em vigor, ao menos por algum tempo, disposições normativas já julgadas

A esse respeito, ver, por exemplo, os julgamentos das ações diretas de inconstitucionalidade de números 1.104, 1.127, 2405, 1344, 1.417, 3.324, 3.046, 2.652, 2.596, 2.084, 2.087 e 1.797.

8 Prefere-se o termo decretação à declaração, na medida em que a possibilidade de estabelecimento de eficácia ex nunc ou diferida para momento futuro determinado pelo Tribunal põe claro o caráter constitutivo, e não meramente declaratório, da decisão de inconstitucionalidade. 
inconstitucionais. Contudo, ainda não se vislumbra em tais decisões uma atividade materialmente legislativa em sentido estrito, uma vez que, repetindo as palavras de TAVARES, não estabelecem a "composição inaugural de comandos de caráter geral", vale dizer, não criam enunciado normativo novo, limitando-se a interpretar, ou "manipular", aqueles já expressa ou implicitamente postos no ordenamento?.

\subsection{Das Açóes Constitucionaispara o Controle da Omissáo Inconstitucional}

Coerente com o seu caráter detalhista e dirigente, cuja concretização demanda intensa atividade regulamentadora infraconstitucional, sobretudo no tocante ao extenso rol de direitos fundamentais, a Constituição Federal de 1988 previu duas ações especialmente destinadas ao enfrentamento da omissão inconstitucional, cujos efeitos interessam diretamente ao exame da atuação normativa do STF a que se propõe o presente artigo.

\subsubsection{Açâo Direta de Inconstitucionalidade por Omissão}

A Constituição Federal de 1988 deixou claro que a ação direta constitui sede própria para o controle abstrato, não só de atos inquinados de inconstitucionais, como, também, de omissões inconstitucionais, ao prever expressamente, no art.103, $\$ 2^{\circ}$, os efeitos da declaração da omissão inconstitucional. A partir de tal dispositivo constitucional, passou-se a falar numa "ação direta de inconstitucionalidade por omissão", processo objetivo de controle abstrato destinado à defesa da ordem jurídica constitucional frente à omissão inconstitucional, em que os legitimados ativos (CF, art.103, caput) agem a bem do interesse público, e não de interesse próprio. Tal ação, no entanto, somente recebeu tipificação legal, com o advento da Lei n.12.063, de 27 de outubro de 2009, que acrescentou ao texto da Lei n.9.868/99 o Capítulo II-A, arts.12-A a 12-H, estabelecendo a respectiva disciplina processual, que não acrescentou qualquer novidade significativa em relação ao que já vinha sendo praticado pelo STF.

9 Nesse sentido, referindo-se especificamente às sentenças aditivas e substitutivas, CRISAFFULI (1984, p.407-408) acentua que "non è esatto, infatti, che la Corte, nei casi in ogetto, finisca per esercitare una funzione legislativa, che non le spetta, sostituendosi agli organi a questa costituzionalmente preposti” [...] "nelle ipotesi testè accenate, la Corte non crea, essa, liberamente (come farebbe Il legislatore) la norma, ma si limita a individuare quella - già implicata nel sistema, e magari addirittura ricavabile dalle stesse disposizioni costituzionali di cui há fatto applicazione - mediante la quale riempire immediatamente la lacuna che altrimenti resterebbe aperta nella disciplina della matéria, cosi conferendo alla pronuncia adottata capacita autoapplicativa". Da mesma forma, MEDEIROS (1999, p.501) adverte que "numerosos autores esforçam-se por sublinhar que não está em causa o exercício de uma função substancialmente criativa $e x$ nibilo, verificando-se tão-somente a extracção de um quid iuris já presente - de modo cogente e vinculativo para o próprio legislador - no ordenamento". 
Da literalidade do $\$ 2^{\circ}$ do art.103, da Constituição Federal, extrai-se, em princípio, a expressa limitação dos efeitos da decisão proferida na ação direta de inconstitucionalidade por omissão, porquanto estatuído que, declarada a inconstitucionalidade por omissão, será dada ciência ao Poder competente para a adoção das providências necessárias e, em se tratando de órgão administrativo, para fazê-lo em trinta dias $\left(\operatorname{art} .103, \$ 2^{\circ}\right)$. Como se vê, a Constituição prevê uma eficácia mandamental com assinatura de prazo para que seja suprida a omissão apenas em relação a órgãos administrativos. Quando a omissão for do legislador, segundo a literalidade do enunciado constitucional, restará apenas a declaração da mora legislativa e uma comunicação ao órgão constitucional moroso, que, sequer contando com uma assinatura de prazo e desacompanhada de qualquer cominação, nem chega a configurar uma eficácia mandamental propriamente dita. Trata-se de texto evidentemente apegado à clássica concepção de "separação de poderes", de acordo com a qual, estando os três "poderes" no mesmo patamar, não se faz cabível uma ordem emanada do Judiciário para o Legislativo.

A principal inovação introduzida pela Lei n.12.063/2009 pode ser identificada na redação dada ao novel art.12-F da Lei n.9.868/99 que prevê a possibilidade de que, em caso de excepcional urgência e relevância da matéria, o Tribunal por decisão da maioria absoluta de seus membros, ouvidos os órgãos ou autoridades responsáveis pela omissão inconstitucional, conceda medida cautelar, que, segundo o $\$ 1^{\circ}$, "poderá consistir na suspensão da aplicação da lei ou do ato normativo questionado, no caso de omissão parcial, bem como na suspensão de processos judiciais ou de procedimentos administrativos, ou ainda em outra providência a ser fixada pelo Tribunal". Merece especial atenção a parte final do dispositivo, ao possibilitar, sem especificar, nem limitar, "outra providência a ser fixada pelo Tribunal", abrindo a possibilidade de o STF, a bem da preservação do Direito Constitucional, naquilo em que ameaçado pela omissão em causa, lançar mão das técnicas decisórias superadoras do dogma do "legislador negativo", originadoras de decisões de cunho normativo em sentido amplo, de modo a assegurar eficácia e efetividade à ordem constitucional, quando manifesta a insuficiência da decisão meramente declaratória para cumprir tal desiderato (VIANNA, 2013, p.245)

Claro exemplo disso foi proporcionado pelo recente deferimento liminar de medida cautelar na ADO 23 (DJe 31/01/2013). Trata-se de ação direta de inconstitucionalidade por omissão ajuizada pelos Governadores dos Estados da Bahia, Maranhão, Minas Gerais e Pernambuco, em razão de alegada omissão do Congresso Nacional quanto ao dever de legislar previsto no art.161, II, da Constituição Federal, segundo o qual cabe à lei complementar "II - estabelecer normas sobre a entrega dos recursos de que trata o art.159, especialmente sobre os critérios de rateio dos fundos previstos em seu inciso I, objetivando promover o equilíbrio socioeconômico entre Estados e entre Municípios". Aduzem que o rateio dos recursos era assegurado aos entes federados nos termos da Lei Complementar 62, de 28 de dezembro de 1989 , cujos art. $2^{\circ}$, I e II, $\$ \$ 1^{\circ}, 2^{\circ}$ e $3^{\circ}$, e anexo único, 
foram julgados inconstitucionais pelo Plenário do STF, no julgamento das ADIs 875, 1.987, 2.727 e 3.243 , tendo assegurada, no entanto, a sua aplicação até 31 de dezembro 2012. Ocorre que o prazo assinado pelo STF expirou, sem que o Congresso Nacional tenha suprido a lacuna legal derivada da aludida declaração de inconstitucionalidade. Daí porque requereram a concessão liminar de medida cautelar, que determinasse solução provisória para a omissão legislativa verificada, mediante a manutenção da vigência do art. $2^{\circ}$, incisos I e II, $\$ \Phi 1^{\circ}, 2^{\circ}$ e $3^{\circ}$, bem como do anexo único, da Lei Complementar n.62/89, até que o órgão omisso adote as providências necessárias para disciplinar a matéria. O Ministro Ricardo Lewandowski, então no exercício da Presidência do Tribunal, houve por deferir em parte o pleito cautelar, ad referendum do plenário, para:

\begin{abstract}
garantir aos Estados e ao Distrito Federal o repasse, pela União, das verbas do fundo a que alude o art.159, I, a, da Constituição da República, no percentual nele estabelecido, em conformidade com os critérios anteriormente vigentes, por mais 150 (cento e cinquenta dias), a contar da intimação desta medida cautelar, desde que não sobrevenha nova disciplina jurídica, sem prejuízo de eventuais compensações financeiras, entre os entes federados, a serem eventualmente definidas em lei complementar.
\end{abstract}

Cuida-se, assim, de decisão de nítido cunho normativo em sentido amplo, na medida em que tem o condão de prorrogar a vigência de dispositivos legais já declarados inconstitucionais, de modo a evitar vazio legislativo potencialmente mais gravoso do que a própria inconstitucionalidade declarada.

De notar-se, acima de tudo, que o STF há muito vem empregando as aludidas técnicas ditas atípicas, tomando decisões de natureza normativa em sentido amplo, para muito além de meramente declaratórias, em sede de ação direta, revelando uma interpretação evolutiva do regramento dos efeitos das decisões proferidas nesta sede processual. É o caso, por exemplo, das decisões prolatadas nas ADIs de ns.1.105, 1.127, 2.240, 2.652, 3.105, 3.316, 3.489, 3.682, 3689 e 4277, evidenciando que, diversamente do que, à primeira vista, pode sugerir a literalidade do texto constitucional, não há uma só e específica carga eficacial para as decisões de procedência de ações diretas de inconstitucionalidade por omissão.

\title{
5.2.2 Mandado de Injunção
}

Já o mandado de injunção constitui controle, em princípio $^{10}$, concreto, cabível "sempre que a falta de norma regulamentadora torne inviável o exercício dos

10 Diz-se "em princípio", porque se adota aqui a tese de que as decisões proferidas pelo STF em mandado de injunção, na esteira na nítida objetivação por que passa o processo constitucional perante este Tribunal, mesmo mediante provocação de titular de direito individual, devem ter eficácia geral, convertendo-se, assim, em controle abstrato. 
direitos e liberdades constitucionais e das prerrogativas inerentes à nacionalidade, à soberania e à cidadania" (CF, art.5 , LXXI).

Mas, se o art.103, $\$ 2^{\circ}$, da Constituição Federal é expresso quanto aos efeitos da declaração da omissão inconstitucional em ação direta, embora, como visto, superado em sua literalidade estrita pela interpretação evolutiva da jurisprudência do STF, o art. $5^{\circ}$, LXXI, da Lei Maior, ao revés, prima pela imprecisão, não delimitando claramente o objeto da tutela, não indicando a legitimação passiva para a ação e, principalmente, não explicitando a natureza do provimento jurisdicional almejado, isto é, não diz, afinal, o que caberia ao órgão julgador fazer, dando azo a persistentes controvérsias. Não bastasse, o mandado de injunção brasileiro longe está de encontrar plena correspondência em qualquer instrumento processual estrangeiro que pudesse constituir parâmetro seguro à sua exata compreensão. Controverte-se, até mesmo, acerca da necessidade, ou não, da configuração da mora legislativa, para o cabimento da ação.

Certo é, no entanto, que tal ação constitucional especial abarca primordialmente a tutela dos direitos fundamentais, e o faz sem a expressa restrição de efeitos decisórios imposta à ação direta de inconstitucionalidade por omissão.

Mais do que isso, ao referir-se a "exercício", o texto constitucional evidentemente diz com a efetividade de um direito, que, repita-se, supõe a eficácia da respectiva norma definidora, o que demanda uma decisão com efeitos diretos e constitutivos. Constitutivos, a fim de que a decisão proferida realmente viabilize o exercício do direito, cumprindo a sua finalidade constitucionalmente determinada. Diretos, porque a tarefa de suprir o vazio de regulamentação é constitucionalmente atribuída ao julgador, no caso do presente estudo o STF, não se lhe facultando a sua delegação, tampouco à sua devolução ao órgão constitucional moroso.

De notar-se, outrossim, que embora franqueie de forma ampla legitimidade ativa a qualquer titular de direito ou liberdade individual, bem como, de prerrogativa inerente à soberania, à nacionalidade ou à cidadania, o que, à primeira vista, pode sugerir o cabimento de decisão com eficácia restrita ao caso concreto, na tutela do interesse individual do impetrante, a literalidade da previsão constitucional de nenhuma forma impõe restrita eficácia inter partes ao julgamento da ação, não contendo nenhuma expressão que denote qualquer limitação de efeitos vinculada à pessoa do impetrante, diversamente do que ocorre no tocante ao habeas corpus ("alguém"), ao mandado de segurança ("direito líquido e certo") e ao habeas data ("informações relativas à pessoa do impetrante"). Ao revés, a partir de uma interpretação sistemática, pode-se concluir que, se a regulamentação cuja falta obsta o exercício do direito, liberdade ou prerrogativa tem caráter geral, então à decisão do STF destinada a suprir tal lacuna se deve atribuir idêntica abrangência subjetiva. Impõe-se estabelecer, neste caso, uma nítida distinção entre a legitimação ativa para 
a ação e os limites subjetivos dos efeitos da decisão, a exemplo do que ocorre na ação popular. É bem verdade que, no mandado de injunção, diversamente da ação popular, o autor da ação busca a tutela de direito próprio e perfeitamente individualizável, o que não impede, todavia, que a decisão do STF beneficie, desde logo, a todos os titulares de idêntico direito ou prerrogativa, evitando a desnecessária, dispendiosa e francamente irracional multiplicação de ações com idêntico objeto.

Para além disso, importa reconhecer no mandado de injunção instrumento próprio para assegurar efetividade ao próprio $₫ 1^{\circ}$, do art. $5^{\circ}$, da Constituição federal, não por assegurar aplicabilidade imediata aos direitos fundamentais carentes de regulamenteção, já que, ao revés, é, ele próprio, um instrumento de mediação concretizadora, mas, sim, porque instrumentaliza o cumprimento do dever de atuação estatal - no caso normativa - tendente a garantir a máxima eficácia e efetividade aos direitos fundamentais decorrente do mandado de otimização extraído do mesmo dispositivo constitucional, que vincula, não apenas os órgãos legislativos, como também o Judiciário e, mais especificamente, o STF aqui enfocado.

Mesmo assim, a despeito da evolução da jurisprudência do STF, ainda reina considerável controvérsia acerca da carga eficacial das decisões proferidas em sede de mandado de injunção, podendo-se identificar quatro grandes posições doutrináriojurisprudenciais a respeito: a) meramente declaratória, ou não-constitutiva; b) constitutiva individual direta; c) constitutiva individual mediata ou intermediária; d) constitutiva geral ${ }^{11}$.

A posição meramente declaratória, ou não-constitutiva, foi a primeira adotada pela jurisprudência do STF, tendendo a equiparar os efeitos da decisão do mandado de injunção aos da ação direta de inconstitucionalidade por omissão, de modo a restringi-los à mera declaração da mora legislativa, seguida de comunicação ao órgão constitucional moroso, que sequer se reveste de efetiva eficácia mandamental. Tal posição evidentemente não atende à finalidade de assegurar efetividade ao direito esvaziado de eficácia pela mora legislativa, razão pela qual não cumpre o desiderato constitucional e absolutamente não atende aos primados mais elevados de Justiça Constitucional. Tomem-se, como exemplos, os sucessivos mandados de injunção providos com eficácia meramente declaratória em relação à questão da omissão de regulamentação do direito fundamental ao aviso prévio proporcional ao tempo de serviço (MI 369-DF, MI 95-RR, MI 278-MG, MI 695-MA), cujos resultados absolutamente não serviram aos trabalhadores titulares do direito em causa, não constituindo sequer estímulo para a atuação do legislador moroso. Não

11 Classificação baseada naquela proposta por MORAES (2006, p.161-166) em: não concretista; concretista individual direta; concretista individual intermediária e concretista geral. Embora o autor utilize as expressões "eficácia não concretista" e "eficácia concretista”, prefere-se, aqui, falar em eficácia meramente declaratória e eficácia constitutiva, a fim de evitar qualquer confusão em relação aos controles concreto e abstrato de constitucionalidade, já que, eficácia constitutiva pode haver, tanto em sede de controle concreto, como de controle abstrato. 
se pode olvidar, a esse respeito, que o exercício do direito fundamental social em tela somente restou viabilizado com o advento da Lei n.12.506, de 11 de outubro de 2011, quando o STF, revisando o posicionamento anterior, encontrava-se na declarada iminência de regular supletivamente a matéria.

O mesmo se diga em relação aos mandados de injunção de ns.323 e 362 (DJ 09/12/994), referentes à falta de regulamentação do art.192, \3 ${ }^{\circ}$ da Constituição Federal, bem como ao mandado de injunção número 20 (DJ 15/05/1994), que teve por objeto a ausência de regulamentação do direito de greve dos servidores públicos, previsto no art.37, VII, da Constituição Federal, todos julgados com efeito meramente declaratório, que se revelou absolutamente inútil ao exercício dos direitos em causa, não servindo, consequentemente, à própria razão de ser do mandado de injunção, expressa no texto constitucional que o instituiu. No que tange ao direito à limitação dos juros reais ao percentual de $12 \%$ ao ano, não só não houve solução normativa provedora da sua eficácia, como ao cabo, o próprio art.192, $\int 3^{\circ}$, da Constituição Federal foi definitivamente extirpado do ordenamento, por obra da emenda constitucional n.40, de29 de maio de 2003. Já o direito de greve dos servidores públicos somente recebeu regulamentação, quando o próprio STF, em viragem diametral de seu posicionamento anterior, houve por regular supletivamente a matéria com eficácia geral, como adiante se destacará.

A posição constitutiva individual direta admite que o STF possa suprir diretamente a lacuna legislativa obstativa do exercício do direito em questão, porém com efeitos subjetivos limitados ao atendimento do interesse do autor da ação, sob o entendimento de que, tratando-se de processo subjetivo, a decisão possui eficácia considerada a relação jurídica nele revelada. Cuida-se de posição ainda hoje verificada em julgamentos do STF (por exemplo, MI 758, MI 721, MI 795 e MI 108), que é aqui rejeitada porque, à toda evidência, tenta harmonizar a eficácia constitutiva da decisão com as concepções de rígida separação de poderes e do Tribunal Constitucional como "legislador negativo", que, como reiteradamente ressaltado, são incompatíveis com a ideia de Justiça Constitucional consentânea com o Estado Constitucional de Direito, vale dizer, nega a possibilidade de o STF suprir provisoriamente a lacuna legislativa com a eficácia geral própria do diploma emanado do Poder Legislativo omitido. A prevalecer tal posição, seria de concordarse com o questionamento de BARROSO (2000, p.173) em relação à própria utilidade e necessidade da existência desta ação, que, no panorama da tímida jurisprudência do STF, afigurar-se-ia suprível pelo velho mandado de segurança. É justamente a possibilidade de suprir a lacuna de regulamentação com eficácia erga omnes, para a efetivação do $\operatorname{art} .5^{\circ}, \$ 1^{\circ}$ da Constituição Federal, que diferencia o mandado de injunção, conferindo-lhe relevância e razão de existir.

A posição constitutiva individual intermediária sustenta a possibilidade de que o STF supra a lacuna legislativa em favor do autor da ação, mas de forma 
mediata, isto é, somente decorrido in albis o prazo assinado ao legislador moroso para suprir a lacuna em questão. Assim decidiu o STF, por exemplo, nos mandados de injunção de ns.283, 232 e 284. Tal orientação, além de apresentar, segundo o que aqui se sustenta, os mesmos problemas da corrente anterior, encerra uma flagrante contradição. Isso porque, num primeiro momento, notifica o legislador moroso para que supra a lacuna legal, evidentemente com a eficácia geral própria de um diploma editado pelo Legislativo. Se o legislador moroso não o fizer, supre a lacuna legislativa apenas em favor do autor da ação, e não com a eficácia geral que teria o diploma omitido.

Por tais razões, sustenta-se, aqui, reitere-se, que as decisões do STF em sede de mandado de injunção devem ter eficácia constitutiva, imediata e geral, a fim de que, desde logo, seja assegurado o exercício do direito fundamental violado pela omissão legislativa a todos aqueles que preencham os requisitos a tanto necessários, o que se afigura consentâneo com a objetivação do processo perante o Tribunal Constitucional, que não tem por missão precípua satisfazer direitos subjetivos individuais, mas, sim, a preservar a ordem constitucional (Cf, art.102, caput). Ademais, evitando a proliferação de processos ensejadora do risco de prolação de decisões díspares para casos análogos, serve aos princípios da isonomia, economia processual, celeridade e segurança jurídica.

A partir de tal posicionamento, tem-se uma hipótese em que, provocado em sede de controle concreto de omissão inconstitucional, o STF tem a possibilidade de exercer controle abstrato, proferindo decisão com eficácia erga omnes.

Esta orientação restou acolhida pelo STF nos paradigmáticos julgamentos dos mandados de injunção de números 670-ES, 708-DF e 712-PA (DJe 30/10/2008), que marcaram viragem diametral no entendimento do Tribunal, que houve por suprir a lacuna legal relativa à regulamentação do direito de greve dos servidores públicos, previsto no art.37, VII, da Constituição Federal, determinando a aplicação - com ressalvas, acréscimos e alterações, frise-se - da Lei n.7783/89, que regula o direito de greve dos trabalhadores do setor privado, aos movimentos paredistas do setor público, de modo a assegurar o exercício do direito até que o legislador venha a regular a matéria.

Na ementa do acórdão de julgamento do mandado de injunção 712, em que foi relator o Ministro Eros Roberto Grau, foi destacada expressamente a superação da jurisprudência anterior do próprio Tribunal, apegada aos dogmas da "separação de poderes" e do Tribunal como "legislador negativo", para admitir-se, não só como cabível, mas, como imperiosa, uma atuação normativa positiva do STF: 
[...] ALTERAÇÃO DO ENTENDIMENTO ANTERIOR QUANTO À SUBSTÂNCIA DO MANDADO DE INJUNÇÃO. PREVALÊNCIA DO INTERESSE SOCIAL. INSUBSISTÊNCIA DO ARGUMENTO SEGUNDO O QUAL DAR-SE-IA OFENSA À INDEPENDÊNCIA E HARMONIA ENTRE OS PODERES (ART.2 $2^{\circ}$ DA CONSTITUIÇÃO DO BRASIL) E À SEPARAÇÃO DOS PODERES (ART.60,§4\%., III, DA CONSTITUIÇÃO DO BRASIL). INCUMBE AO PODER JUDICIÁRIO PRODUZIR A NORMA SUFICIENTE PARA TORNAR VIÁVEL O EXERCÍCIO DO DIREITO DE GREVE DOS SERVIDORES PÚBLICOS, CONSAGRADO NO ART.37, VII, DA CONSTITUIÇÃO DO BRASIL [...]

14. O Poder Judiciário está vinculado pelo dever-poder de, no mandado de injunção, formular supletivamente a norma regulamentadora de que carece o ordenamento jurídico. 15. No mandado de injunção o Poder Judiciário não define norma de decisão, mas enuncia o texto normativo que faltava para, no caso, tornar viável o exercício do direito de greve dos servidores públicos. 16. Mandado de Injunção julgado procedente, para remover o obstáculo decorrente da omissão legislativa e, supletivamente, tornar viável o exercício do direito consagrado no art.37, VII, da Constituição do Brasil.

No julgamento do mandado de injunção n.670 restou nítida, a partir da ressalva feita pelo relator para o acórdão, Ministro Gilmar Ferreira Mendes, a eficácia ultra partes da decisão:

[...] Considerada a omissão legislativa alegada na espécie, seria o caso de se acolher a pretensão, tão-somente no sentido de que se aplique a Lei n.7.783/1989 enquanto a omissão não for devidamente regulamentada por lei específica para os servidores públicos civis (CF, art.37, VII). $4.3 \mathrm{Em}$ razão dos imperativos da continuidade dos serviços públicos, contudo, não se pode afastar que, de acordo com as peculiaridades de cada caso concreto e mediante solicitação de entidade ou órgão legítimo, seja facultado ao tribunal competente impor a observância a regime de greve mais severo em razão de tratar-se de "serviços ou atividades essenciais", nos termos do regime fixado pelos arts. $9^{\circ}$ a 11 da Lei n.7.783/1989. Isso ocorre porque não se pode deixar de cogitar dos riscos decorrentes das possibilidades de que a regulação dos serviços públicos que tenham características afins a esses "serviços ou atividades essenciais" seja menos severa que a disciplina dispensada aos serviços privados ditos "essenciais". 4.4. O sistema de judicialização do direito de greve dos servidores públicos civis está aberto para que outras atividades sejam submetidas a idêntico regime. Pela complexidade e variedade dos serviços públicos e atividades estratégicas típicas do Estado, há outros serviços públicos, cuja essencialidade não está contemplada pelo rol dos arts. $9^{\circ}$. a 11 da Lei n.7.783/1989. Para os fins desta decisão, a enunciação do regime fixado pelos arts. $9^{\circ}$ a 11 da Lei n.7.783/1989 é apenas exemplificativo (numerus apertus). 
O mesmo Ministro, comentando o julgamento dos mandados de injunção em tela, observa que o Tribunal adotou "uma moderada sentença de perfil aditivo, introduzindo modificação substancial na técnica de decisão do mandado de injunção" (MENDES, 2011, p.1334). Não só isso. É preciso constatar que o STF foi além. É que, no caso, não estendeu simplesmente a aplicação da Lei n.7783/89 aos movimentos paredistas do serviço público, como se os servidores públicos devessem estar abrangidos pelo âmbito de aplicação daquele diploma, como seria próprio de uma típica decisão aditiva. A regra do art.37, VII, da Constituição Federal, que determina a edição de lei específica para regular a greve dos servidores é bastante para afastar por completo tal conjectura. Na realidade, embora apropriando-se, em grande parte, do texto normativo da Lei n.7783/89, o que o STF fez foi regular originariamente e com efeito geral12 a matéria. Sim, o STF legislou.

Tanto é assim, que, no julgamento do mandado de injunção n.670, o próprio relator, Ministro Gilmar Ferreira Mendes, houve por disciplinar, também, a competência para o julgamento dos dissídios sobre greves do setor público, nos âmbitos da Justiça Federal e da Justiça Estadual, até a edição de legislação específica pertinente:

[...] 6.3. Até a devida disciplina legislativa, devem-se definir as situações provisórias de competência constitucional para a apreciação desses dissídios no contexto nacional, regional, estadual e municipal. Assim, nas condições acima especificadas, se a paralisação for de âmbito nacional, ou abranger mais de uma região da Justiça Federal, ou ainda, compreender mais de uma unidade da Federação, a competência para o dissídio de greve será do Superior Tribunal de Justiça (por aplicação analógica do art.2, I, "a", da Lei n.7.701/1988). Ainda no âmbito federal, se a controvérsia estiver adstrita a uma única região da justiça federal, a competência será dos Tribunais Regionais Federais (aplicação analógica do art.6 ${ }^{\circ}$ da Lei n.7.701/1988). Para o caso da jurisdição no contexto estadual ou municipal, se a controvérsia estiver adstrita a uma unidade da Federação, a competência será do respectivo Tribunal de Justiça (também por aplicação analógica do art. $6^{\circ}$ da Lei n.7.701/1988). As greves de âmbito local ou municipal serão dirimidas pelo Tribunal de Justiça ou Tribunal Regional Federal com jurisdição sobre o local da paralisação, conforme se trate de greve de servidores municipais, estaduais ou federais ${ }^{12}$.

12 Ainda em relação à abrangência subjetiva dos efeitos da decisão em sede de mandado de injunção, vale atentar para o quanto enfatizado por MENDES (2011, p.1334-1335): "O que se evidencia é a possibilidade de as decisões nos mandados de injunção surtirem efeitos não somente em razão do interesse jurídico de seus impetrantes, estendendo também seus efeitos normativos para os demais casos que guardem similitude. Assim, em regra, a decisão em mandado de injunção, ainda que dotada de caráter subjetivo, comporta uma dimensão objetiva, com eficácia erga omnes, que serve para tantos quantos forem os casos que demandem a concretização de uma omissão geral do Poder Público, seja em relação a uma determinada conduta, seja em relação a uma determinada lei" 
Já no julgamento do mandado de injunção n.712, o relator, Ministro Eros Roberto Grau, considerando as especificidades do serviço público e da relação estatutária entre servidores e Estado, que muito se diferenciam da relação entre capital e trabalho do setor privado, ressalvou:

Por isso tenho que a Lei n.7.783, de 20.06.89, atinente à greve dos trabalhadores em geral, não se presta, sem determinados acréscimos, bem assim algumas reduções do seu texto, a regular o exercício dos direitos de greve pelos servidores públicos. Este reclama, em certos pontos, regulação peculiar, mesmo porque "serviços ou atividades essenciais" e "necessidades inadiáveis da coletividade" não se superpõem a "serviços públicos"; e vice-versa. Trata-se aí de atividades próprias do setor privado, de um lado, ainda que essenciais, voltadas ao atendimento de necessidade inadiáveis da coletividade, e de atividades próprias do Estado, de outro.

E assim concluiu:

Isto posto, a norma, na amplitude que a ela deve ser conferida no âmbito do presente mandado de injunção, compreende conjunto integrado pelos arts. $1^{\circ}$. ao $9^{\circ}$., 14, 15 e 17 da Lei n.7783/89, com as alterações necessárias ao atendimento das peculiaridades da greve nos serviços públicos, que introduzo no art. $3^{\circ}$ e seu parágrafo único, no art. $4^{\circ}$, no parágrafo único do $\operatorname{art} .7^{\circ}$, no art. $9^{\circ}$ e seu parágrafo único e no art.14. Este, pois, é o conjunto normativo reclamado, no quanto diverso do texto dos preceitos mencionados da Lei n.7.783/89:[...]

Ao ditar nova redação aos referidos dispositivos da Lei n.7.783/1989, especificamente para a sua aplicação às greves do setor público, evidentemente foi além de proferir decisão aditiva. Repita-se, legislou.

Portanto, exsurge claro, aqui, o exercício de uma função materialmente legislativa ${ }^{13}$ em sentido estrito pela Excelsa Corte brasileira, isto é, a atuação do STF como "legislador positivo", que, pelas razões expostas no item 4 retro, de forma alguma conflita com o modelo constitucional de repartição e compartilhamento orgânico-funcional do exercício do poder do Estado, tampouco afronta o princípio democrático.

13 Diz-se, aqui, materialmente legislativa, apenas para distingui-la da atividade formalmente legislativa, considerando-se ser esta última a desenvolvida segundo o processo legislativo disciplinado na Seção VIII, do Capítulo I, do Título IV, da Constituição Federal, já que, na essência, são indistintas. 


\section{Pressupostos, Características e Limites da Atuação do STF como Legislador Positivo}

Por fim, impende ressalvar que a atuação do STF como "legislador positivo", que aqui se sustenta, tem lugar à vista de pressupostos claramente delineados, possui características bem determinadas e correlatos limites igualmente nítidos.

Sendo a Constituição que dispõe sobre a competência dos órgãos que institui, e, assim, sobre a própria repartição do exercício das funções estatais, o primeiro pressuposto para uma atuação materialmente legislativa em sentido estrito por parte do Tribunal Constitucional reside na existência de autorização constitucional para tanto, isto é, na fixação de competência constitucional que imponha um agir que tal de parte do STF. Tal autorização é encontrada no art.102, I, “q”, combinado com o art. $5^{\circ}$, LXXI, ambos interpretados à luz da função precípua de guarda da Constituição acometida ao STF pela cabeça do referido art.102, bem como do princípio da máxima seja tal que inviabilize o exercício do direito, liberdade ou prerrogativa em causa.eficácia e efetividade dos direitos fundamentais, consagrado no $\operatorname{art.} 5^{\circ}, \$ 1^{\circ}$, todos da Constituição Federal.

Constatada a autorização constitucional para o desempenho de atividade materialmente legislativa por parte do STF e que tal competência encontra lugar especificamente no julgamento do mandado de injunção, os demais pressupostos do seu cabimento se identificam com os pressupostos do cabimento do próprio writ, quais sejam: a) que verse sobre direito ou liberdade constitucional, ou ainda, sobre prerrogativa inerente à nacionalidade, à soberania ou à cidadania, instituído por norma de eficácia limitada, isto é, por enunciado não dotado de densidade normativa suficiente para produzir, independentemente de regulamentação, a totalidade de seus efeitos, vale dizer, a plenitude de sua eficácia e aplicabilidade; b) a ocorrência de omissão normativa inconstitucional, que prive de regulamentação o direito, liberdade ou prerrogativa em questão; c) que a omissão normativa regulamentadora inconstitucional, total ou parcial,

Tem-se, a partir disso, que a atuação supletiva do STF como legislador positivo, que se vislumbra em sede de mandado de injunção, somente pode ter lugar diante de uma irretorquível omissão regulamentar inconstitucional, discordando-se, pois, da tese de que o cabimento do mandado de injunção independeria da configuração de mora legislativa, destinando-se a proteger os direitos constitucionais também contra as meras lacunas técnicas, ainda que, com o passar dos anos, tais lacunas tendam a deslocar-se para o eixo da omissão inconstitucional (CLÈVE, 2000, p.365). Embora a tese em exame, para além de respeitável, seja sedutora, na medida em que, sem dúvida, aponta no sentido da máxima eficácia e efetividade dos direitos fundamentais, aqui defendida, há de ser vista com cautela. Isso porque a positivação de determinados direitos fundamentais no texto constitucional originário em normas 
de baixa densidade normativa deve ser interpretada como opção do constituinte de reservar espaço à regulamentação pelo legislador infraconstitucional, por meio de lacunas técnicas, opção esta que não seria respeitada se ao Tribunal Constitucional fosse dado anterpor-se ao legislador para colmatá-las. Assim, admitir-se o cabimento do mandado de injunção, sem que esteja configurada a mora legislativa, implica aceitar, a priori, a anteposição ou a superposição da atuação normativa do Tribunal à do legislador, configurando, aí sim, por via de consequência, invasão de competência e usurpação de função, em afronta ao regramento constitucional pertinente à repartição do exercício das funções estatais, na medida em que o Tribunal estaria assumindo o protagonismo que a Constituição reserva ao legislador neste mister (VIANNA, 2013, p.282-283).

Destarte, a atuação de natureza legislativa em sentido positivo do STF se caracteriza como estritamente supletiva, porquanto cabível somente se caracterizada a mora do órgão constitucional em princípio competente para a edição do ato omitido; condicionada, porque balizada pelo conjunto dos direitos fundamentais em sua perspectiva objetiva, pelos princípios constitucionais, pelos objetivos fundamentais e pelo próprio texto da Lei Maior; tópica, de modo a suprir pontualmente o vazio normativo constatado apenas no quanto necessário à efetividade do direito fundamental violado pela omissão inconstitucional; e provisória, na medida em que a solução supletiva dada pelo STF pode, e deve, a qualquer tempo, ser substituída pela edição do ato normativo reclamado do órgão constitucional moroso, cuja competência permanece íntegra.

Da observância de tais características resultam claros limites à autuação do STF como legislador positivo. Sendo supletiva a sua atuação, evidentemente, em hipótese alguma, pode sobrepor-se ao mister do legislador, para normatizar matéria já regulada em lei, tampouco, como frisado, antecipar-se à ação do legislador, quando não perfeitamente caracterizada a mora legislativa.

Sendo tópico, o seu agir resta claramente limitado do ponto de vista material, não sendo dado ao Tribunal legislar sobre a matéria enfocada em termos amplos, para estabelecer, por exemplo, políticas públicas. E tal limitação de abrangência material deve fazer redobrar a cautela no exercício legislativo pelo Tribunal, na medida em que este, embora não só possa como deva, o quanto possível, antever as consequências políticas, econômicas e sociais da sua decisão de cunho normativo, não tem competência para reger a matéria em termos mais amplos, de modo a estabelecer medidas preparatórias, compensatórias ou de ajuste, não podendo versar, v.g, sobre fontes de custeio ou compensações com outros direitos. Daí porque sobreleva, aqui, a importância da abertura e da democratização do processo constitucional, a fim de que o Tribunal possa colher o máximo de informações sobre a matéria a versar, ampliar e aprofundar o diálogo institucional com os demais órgãos constitucionais e ouvir entidades representativas dos atores sociais 
envolvidos, que serão, ao cabo, os próprios destinatários da decisão de cunho normativo a ser emitida.

Para além disso, importa ter presente que, se a discricionariedade política do legislador quanto ao conteúdo, ao momento, ao alcance, ao prazo e aos objetivos específicos da legislação, já não é irrestrita, porquanto sujeita ao balizamento constitucional, a discricionariedade da atividade legislativa do Tribunal, embora existente, é ainda muito mais limitada, fundando-se em direito geral criado de antemão, residente na própria Constituição. O Tribunal não é, pois, livre para criar o direito, incumbindo-lhe, sim, cumprir, ou fazer cumprir, o programa constitucional, segundo os valores e os princípios que o informam. Nesse sentido, também a atuação do Tribunal como "legislador positivo" não conflita com a tese de KELSEN (1991, p.272) de que a decisão judicial é a continuação, não o começo, da criação do direito.

Observados tais pressupostos, caracteres e limites, a atuação do STF como "legislador positivo" não só não implica usurpação de competências do Legislativo e do Executivo, como, ao revés, coaduna-se perfeitamente com a postura ativa que cabe ao Judiciário no concerto da repartição do exercício de funções estatais a ser observada no Estado Democrático de Direito, sobretudo sob égide de uma Constituição dirigente, de marcante cunho social, como a Constituição brasileira de 1988.

Impõe-se observar, finalmente, que, caso o Projeto de Lei n.6128/2009 venha a ser aprovado e sancionado como lei, implicará retrocesso em relação às mais avançadas decisões do STF, impondo limite legal, atualmente inexistente, à eficácia do mandado de injunção, a ponto de vedar a atuação do Tribunal como "legislador positivo". Isso porque, segundo o art. $9^{\circ}$ do referido projeto a decisão terá eficácia subjetiva limitada às partes, embora, em seu parágrafo primeiro, ressalve, de forma um tanto vaga, a possibilidade de conferir-se-lhe eficácia ultra partes ou erga omnes, "quando isso for inerente ou indispensável ao exercício do direito, liberdade, ou prerrogativa objeto da impetração". Além disso, somente admite a regulação supletiva da matéria, após assinado e transcorrido prazo razoável para que o impetrado promova a edição da norma regulamentadora (art. $\left.8^{\circ}, \mathrm{I}\right)$, determinando claramente, pois, um retrocesso à orientação de uma eficácia constitutiva, individual e mediata da decisão proferida em sede de mandado de injunção, que somente contribui para retardar, ainda mais, o exercício de direitos fundamentais há muito esvaziados de efetividade, ante a natural delonga, tanto do processo judicial, quanto do legislativo, fragilizando, sobremaneira, a tutela do art. $5^{\circ}, \$ 1^{\circ}$ da Constituição Federal. 


\section{CONCLUSÃO}

A título de conclusão, releva destacar que a efetivação da Constituição, no âmbito do constitucionalismo contemporâneo, deve representar, acima de tudo, a busca da eficácia e da efetividade dos direitos fundamentais, pena de restar reduzida à mera figura retórica, vazia de efeitos práticos.

Daí porque exsurge clara a necessidade de assunção de uma postura ativa por parte do STF, operando na condição de Tribunal Constitucional, quanto ao enfrentamento da omissão inconstitucional, seja por meio de uma atuação normativa em sentido amplo, ou mesmo de função materialmente legislativa, portanto, normativa em sentido estrito, para o que, em âmbito mais restrito, foi-lhe conferida competência constitucional em sede de mandado de injunção.

Não se trata de conceber a atividade normativa do Tribunal como panaceia para a concretização do programa constitucional, muito menos de advogar a substituição do legislador pelo julgador, tanto que se afirma o caráter supletivo, provisório e materialmente limitado da atuação normativa do STF, quando cabível. O que não se admite é que a omissão inconstitucional seja respondida com mais omissão, sob o confortável pretexto de homenagear os princípios da democracia e da divisão de "Poderes", compreendidos de modo constitucionalmente inadequado, distantes da função protetiva e promocional da Constituição e da Justiça Constitucional em matéria de direitos fundamentais.

Nessa senda, impende frisar que a ordem constitucional brasileira confere à Justiça Constitucional instrumentos adequados para um efetivo enfrentamento da omissão inconstitucional, desde que bem compreendidos e manejados. As chamadas decisões "interpretativas" e "manipulativas", não expressamente positivadas, mas amplamente assimiladas pela jurisprudência, especialmente as assim chamadas sentenças aditivas, no tratamento da omissão parcial ofensiva ao princípio da igualdade, desempenham importante papel no controle da omissão inconstitucional, não sendo, contudo, suficientes para assegurar efetividade aos direitos fundamentais carentes de regulamentação com suficiente densidade normativa.

Igualmente releva ter presente que a fundamental distinção entre a ação direta de inconstitucionalidade por omissão e o mandado de injunção não reside, nem na legitimação, restrita na primeira e ampla no segundo, nem no objeto, amplo na primeira e limitado no segundo, mas nos respectivos escopos, estando o do mandado de injunção diretamente voltado para a efetivação da norma do $\$ 1^{\circ}$ do $A r t .5^{\circ}$. da Constituição Federal. A compreensão deste fim é imprescindível ao vislumbre da própria razão de ser do mandado de injunção, ao correto dimensionamento dos seus efeitos objetivos e subjetivos e à adequada regulação do instituto, o que não se verifica no Projeto de Lei n.6.128/2009. A possibilidade de originar decisão 
normativa supletiva e provisória com eficácia geral, tal qual a do diploma regulatório omitido, é que justifica a própria existência do mandado de injunção, não suprível por meio do mandado de segurança, tampouco pela pura e simples aplicação do $\operatorname{art.4^{\circ }}$ da Lei de Introdução ao Código Civil.

Assim, negar a legitimidade da atuação legislativa material supletiva (normativa), condicionada, tópica e provisória do STF, é deixar sem resposta satisfatória e suficientemente abrangente o grave problema da omissão inconstitucional; é permitir a mais grave forma de hipertrofia de um "Poder", altamente atentatória ao princípio da repartição do exercício do poder estatal, qual seja, a de recusar-se a fazer o que a Constituição manda fazer; é atentar contra a supremacia da Constituição, contra a sua força normativa e a sua juridicidade; é esvaziar de eficácia e efetividade os direitos fundamentais, reduzindo-os, em alguns casos, a meras e inúteis figuras de retórica, por apego ao velho constitucionalismo da "separação de poderes" e ao dogma da supremacia do legislador.

\section{REFERÊNCIAS BIBLIOGRÁFICAS}

BARROSO, Luís Roberto. O direito constitucional e a efetividade de suas normas: limites e possibilidades da Constituição brasileira. 4. ed. ampl. atual. Rio de Janeiro: Renovar, 2000.

BERNARDES, Juliano Taveira. Controle Abstrato de Constitucionalidade: elementos materiais e princípios processuais. São Paulo: Saraiva, 2004.

CANOTILHO, José Joaquim Gomes. Constituição Dirigente e Vinculação do Legislador: contributo para a compreensão das normas constitucionais programáticas. Coimbra: Coimbra Editora, 1994.

Direito constitucional e teoria da constituição. Coimbra: Almedina, 2003.

CLÈVE, Clèmerson Merlin. A Fiscalização Abstrata da Constitucionalidade no Direito Brasileiro.2.ed. rev., atual. e ampl. São Paulo: Editora Revista dos Tribunais, 2000.

CRISAFULLI, Vezio. Lezioni di diritto costituzionale: l'ordinamento costituzionale italiano: La corte costituzionale. 5. ed. rev. e atual. Padova: Cedam, 1984.

DI MANNO, Thierry. Le juge constitutionnel e la te technique des décisions “interprétatives" en France et en Italie. Paris: Economica, 1997.

DIAS, Gabriel Nogueira. "Legislador negativo" na obra de Hans Kelsen: origem, fundamento e limitações à luz da própria reine rechtshre. Revista Brasileira de Estudos Constitucionais - RBEC. Belo Horizonte, ano 04, n.15, jul/set.2010, p.91-116.

DIMOULIS, Dimitri; LUNARDI, Soraya Gasparetto. O "legislador negativo" no controle judicial de constitucionalidade: reflexões sobre a inaptidão teórica de uma construção. Revista Brasileira de Estudos Constitucionais - RBEC. Belo Horizonte, Ano 04, n.15, jul/set.2010, p.161 -181.

ENTERRÍA, Eduardo García de. La Constitución como norma y el tribunal constitucional. Madrid: Civitas, 2006. 
FIX-ZAMUDIO, Héctor. Breves Reflexiones sobre la naturaleza, estructura y funciones de los organismos jurisdicionales especializados en la resolución de processos constitucionales. Belo Horizonte, Revista LatinoAmericana de Estudos Constitucionais, n.I, jan/jun.2003, p.77-112.

HÄBERLE, Peter. Hermenêutica constitucional: a sociedade aberta dos intérpretes da constituição: contribuição para a interpretação pluralista e "procedimental" da constituição. Tradução de Gilmar Ferreira Mendes. Porto Alegre: Sérgio Antônio Fabris, 1997.

KELSEN, Hans. Jurisdição constitucional. São Paulo: Martins Fontes, 2003.

. Quién debe ser el defensor de la constitución? 2.ed.Madrid:Tecnos, 1995.

Teoria Pura do Direito. Tradução de João Baptista Machado. Revisão para a edição brasileira de Silvana Vieira. 3 ed. São Paulo: Marins Fontes, 1991.

LAMBERT, Edouard. Le gouvernement des juges et la lutte contre la législation sociale aux États-Unis: l'expériénce américaine du controle judiciaire de la constitutionnalité des lois. Paris: Marcel Giard, 1921.

LOEWENSTEIN, Karl. Teoria de la Constitución. Tradução para o espanhol de Alfredo Gallego Anatarte. Barcelona: Editorial A, 1976.

MEDEIROS, Rui. A decisão de inconstitucionalidade: os autores, o conteúdo e os efeitos da decisão de inconstitucionalidade da lei. Lisboa: Universidade Católica, 1999.

MENDES, Gilmar Ferreira. Jurisdição Constitucional: o controle abstrato de normas no Brasil e na Alemanha. 5.ed. São Paulo: Saraiva, 2005, p.267-269 e 296

. COELHO, Inocêncio Mártires. BRANCO, Paulo Gustavo Gonet. Curso de Direito Constitucional. 6 ed. rev. e atual. São Paulo: Saraiva, 2011.

MIRANDA, Jorge. Manual de Direito Constitucional, tomo VI, 2.ed. rev. e atual. Coimbra: Coimbra Editora, 2005.

MORAES, Alexandre de. Direito Constitucional. 20 ed. São Paulo: Atlas, 2006.

SARLET, Ingo Wolfgang. A eficácia dos direitos fundamentais: uma teoria geral dos direitos fundamentais na perspectiva constitucional. 10.ed. rev., atual. e ampl. Porto Alegre: Livraria do Advogado Ed., 2009.

SCHMITT, Carl. La defensa de la Constitución: estúdio acerca de las diversas espécies y possibilidades de salvaguarda de la Constitución. Madrid: Alianza, 2001.

SEGADO, Francisco Fernández. La Justicia Constitucional ante el siglo XXI: la progressiva convergencia de los sistemas americano y europeo-kelseniano. Revista Latino-Americana de Estudos Constitucionais. Belo Horizonte, n.2, jul/dez.2003, p.211-277.

El Control de Constitucionalidad de las omisiones legislativas - algunas cuestiones dogmáticas. Direitos Fundamentais e Justiça. Porto Alegre, ano 3, n.7, abr./jun.2009, p.47-80.

SHAPIRO, Martin. Freedom of Speech: The Supreme Court and Judicial Review,Englewood Cliffs, N.J., Prentice Hall, 1966.

TAVARES, André Ramos. A inconsistência do Tribunal Constitucional como "legislador negativo" em face de técnicas avançadas de decisão da Justiça Constitucional. Revista Brasileira de Estudos Constitucionais RBEC. Ano 04, n.15, jul/set.2010. Belo Horizonte: Fórum, 2010, p.117-130.

Justiça Constitucional: superando as teses do "legislador negativo" e do ativismo de caráter jurisdicional.

Direitos Fundamentais e Justiça. Porto Alegre, ano 3, n.07, abr/jun.2009, p.167-181. 
VIANNA, Rodrigo. O STF como Legislador Positivo: justiça constitucional pela efetividade dos direitos fundamentais. Porto Alegre: PUCRS, 2013. Dissertação (Mestrado em Direito), Faculdade de Direito, Pontifícia Universidade Católica do Rio Grande do Sul, 2013.

\section{INGO WOLFGANG SARLET}

isarlet@pucrs.br

Doutor e Pós-Doutor em Direito pela Universidade de Munique. Professor Titular dos Programas (Mestrado e Doutorado) de Pós-Graduação em Direito da PUCRS. Professor da Escola Superior da Magistratura do Rio Grande do Sul (AJURIS). Juiz de Direito no RS. Coordenador do GEDF (Grupo de Estudos e Pesquisas em Direitos Fundamentais - CNPq)

\section{RODRIGO VIANNA}

rodrigo.viannna@yahoo.com.br

Mestre em Direito pela PUCRS. Advogado. 